\title{
What happened to collective bargaining during the great recession?
}

Jelle Visser ${ }^{1,2}$

Correspondence: jelle.visser@uva.nl ${ }^{1}$ Amsterdam Institute for Advanced Labour Studies (AIAS), P.O. Box 94025, Amsterdam, GA 1090, the Netherlands

${ }^{2}$ Bremen International Graduate School for the Social Sciences (BIGSSS), P.O. Box 330404, Bremen 29344, Germany

\section{望 Springer}

\begin{abstract}
Collective bargaining over labour conditions between unions and employers is a key labour market institution in democratic societies, guaranteed by international and national law. Its coverage, organization and impact have varied over time and across countries. Inclusive bargaining, conducted by employers' associations with a mandate to bargain, and supported by the state, received a strong impulse during the interwar Depression. In the Great Recession a more exclusive version based on enterprise bargaining appears to have been favoured by governments and international agencies. How this relates to changes in bargaining coverage, multi-employer and multi-level bargaining, rules on extension and opening clauses is the subject of this paper, which surveys developments in $38 \mathrm{OECD}$ and EU countries. A distinction is made between long-term and crisis-related changes, and between regulatory and non-regulatory changes during the Great Recession.
\end{abstract}

JEL classification: Collective bargaining (J520), Labour-Management Relations (J530), Trade Unions (J510), Public Policy (J580)

"I regard the growth of wage bargaining as essential. I approve minimum wage and hours regulation."

(John Maynard Keynes, 1-2-1938, letter on recovery policies from the Great Depression to President Roosevelt)

\section{Introduction}

Collective bargaining ${ }^{1}$ involves a process of negotiation between trade unions and employers or employers' organizations to determine terms and conditions of employment. Together with the right to organize, collective bargaining is a fundamental principle and right at work, recognized by the international community. The Right to Organize and Collective Bargaining Convention, 1949 (No. 98) is one of the eight fundamental Conventions of the International Labour Organization (ILO). It guarantees collective bargaining as a voluntary process between independent and autonomous parties, and calls on governments to take "measures appropriate to national conditions [...] to encourage and promote the full development and utilisation of machinery for voluntary negotiation between employers or employers' organisations and workers' organisations, with a view to the regulation of terms and conditions of employment by means of collective agreements' (art 4).

(c) 2016 Visser. Open Access This article is distributed under the terms of the Creative Commons Attribution 4.0 International License (http://creativecommons.org/licenses/by/4.0/), which permits unrestricted use, distribution, and reproduction in any medium, provided you give appropriate credit to the original author(s) and the source, provide a link to the Creative Commons license, and indicate if changes were made. 
For workers, collective bargaining has a protective function - ensuring adequate pay, establishing limits on daily and weekly working time, and regulating other working conditions for those with weak individual negotiating power; a voice or participation function - the collective expression of grievances and participation in the success of the enterprise; and a distributive function - securing a fair share of the benefits of training, technology and productivity growth. For employers, collective bargaining has a key conflict management function - it provides a process for resolving disputes of interest. Managerial control tends to be more acceptable and effective when legitimised through joint rules (Flanders 1968).

Collective agreements and wage regulations like a mandatory minimum wage put a floor in the labour market and thus limit cutthroat competition. This is the aspect defended by Keynes in the quotation above. Stabilizing wages reduces uncertainty about future costs and prices and can thus contribute to raising business and human capital investment decisions, which depend strongly on expectations. Collective bargaining, when sufficiently inclusive and coordinated, offers a mechanism for responsible wage setting, with outcomes that are compatible with price stability and low unemployment (Aidt and Tzannatos 2008; Flanagan 1999; OECD 2006; Traxler and Brandl 2012). Moreover, collective bargaining relieves the state from the complex task of setting standards and solving coordination problems in an area marred with conflicts and risks of non-compliance. It provides the possibility to tailor regulations to the circumstances in an enterprise or industry. In many countries and in EU law it is, moreover, possible to derogate by collective agreement from legal minimum standards on for instance working hours, employment contracting and employee information and consultation in the enterprise.

Compared to individual bargaining or unilateral pay determination, collective bargaining is associated with higher earnings, more security for employees and more earnings equality. In the literature a gap between union and non-union wages, or more properly specified between workers covered and not covered by collective agreements, of 4 (Norway) to 20 percent (Canada) has been reported (Hartog et al. 2002). A study based on ISSP survey data for 1995-99 covering 17 countries found a union or collective bargaining 'mark up' varying from less than 1 percent, negative or insignificant in Sweden, Italy or the Netherlands, 4 percent in Germany, 7 percent in Norway and Spain, rising to more than 20 percent in Japan (Blanchflower and Bryson 2003). A recent study of German wage data found that the gap between the average wages of covered and uncovered workers had risen from 8 to 19 percent between 1999 and 2010, or from 1 to 10 percent if controlled for firm size. The authors concluded that the decline of collective bargaining in Germany in the past two decades - with the coverage rate decreasing from over 80 to under 60 percent - has contributed more to rising wage inequality than international trade (Felbermayr et al. 2014). Addison et al. (2014), using a different methodology and controlling for employee heterogeneity, report a smaller 'wage gap' in Germany of 3-4 percent during the first half of the 2000s. Their analysis shows that in a period of general standstill in wages, workers whose firms abandoned the sectoral agreement experienced a wage loss, albeit decreasing over time, whereas workers whose firms joined the sectoral agreement enjoyed a slightly increasing wage gain. 
Across countries, there is a strong negative association between bargaining coverage and wage inequality measured by the P1/P10 earnings ratio. Coverage accounts for 50 percent of the variance in wage inequality across the 32 OECD member states (Visser et al. 2015). If rising inequality has a negative impact on growth (IMF 2014; OECD 2014), then international and national policy makers should think twice before weakening the institutions that underpin inclusive and coordinated collective bargaining. Of these institutions, multi-employer bargaining above the level of single firms is the most important. The level of bargaining accounts for 70 percent of the cross-national variance in bargaining coverage in a sample of 48 countries (Visser et al. 2015).

In this paper I examine what happened to collective bargaining during the Great Recession, placing the development of the past six years in a longer trend. I focus on developments in three interrelated dimensions that together define whether collective bargaining is inclusive and coordinated: (1) the scope or coverage of collective bargaining and extension of agreements to non-organized firms and workers; (2) the vertical structure or organization of collective bargaining (multi- or single-employer bargaining; the level(s) at which bargaining takes place; the relationship across levels; opening clauses and the involvement of non-union actors); and (3) the horizontal coordination of bargaining behaviour and outcomes across bargaining units.

I distinguish between regulatory and non-regulatory changes, acknowledging that change can result from a modification of the rules or government policies under which collective bargaining operates, or instead occur through behavioural changes within unions, firms and employers' associations and interactions between them. The data are from the Institutional Characteristics of Trade Unions, Wage Setting, State Intervention and Social Pacts (ICTWSS) Database, version 5.0, updated till 2013 or 2014, ${ }^{2}$ and cover 38 countries (Visser 2015). ${ }^{3}$

\section{The scope of collective bargaining}

The Great Recession has not been kind to collective bargaining. Since 2008, whereas summarized over 38 countries the number of employees in employment expanded with 8 million, the number covered by a collective agreement decreased with more than 13 million. The (non-weighted) mean bargaining coverage rate fell from 58 to 52 percent (Fig. 1, left panel). ${ }^{4}$ In absolute numbers this shrinkage is unprecedented since 1945, in relative terms it intensifies a development begun a decade earlier. In the non-European part of the OECD the average coverage rate now stands at just over 20 percent compared to 50 percent in 1980. In CEE coverage has shrunk year after year since free collective bargaining was restored after 1989 and during the Recession the mean dropped by 13 percentage points, from 42 to 29 percent. In Western Europe the coverage rate, averaged over 18 countries, stayed close to 80 percent until 1995 when it began to decline slowly until 72 percent today.

The right-hand panel of Fig. 1 visualises the mean rate of unionization. Basically the same trends emerge, be it that the decline of union density started a decade or more before the decline in bargaining coverage and the level of unionization is, on average, half the level of bargaining coverage. ${ }^{5}$ Union density decreased during the crisis in most countries, prolonging a trend that began much earlier, but in most countries and unlike earlier recessions the fall in bargaining coverage was larger than the decline in unionization. Unfortunately, the lack of annual data on the 

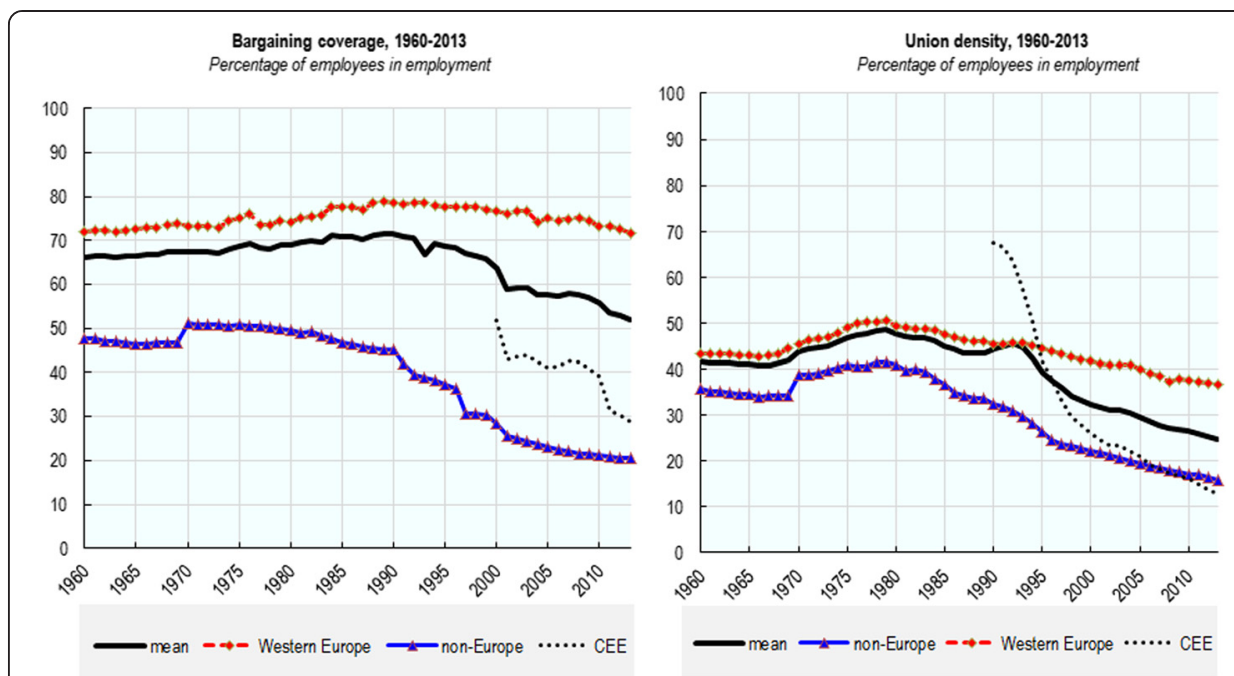

Fig. 1 Mean trends in bargaining coverage and union density, 1960-2013

membership of employers' associations does not allow us to analyse how much of the contraction of bargaining coverage is due to withdrawal from employers' associations.

What is decisive in these differences - across (groups of) countries - is the existence or not of multi-employer bargaining. The level of bargaining explains about three-quarters of the variation in bargaining coverage across countries ( $\mathrm{Rsq}=.77$ ). All the countries in the upper half of Fig. 2 (left panel) are dominated by multiemployer bargaining. Leaving some difficult to classify countries (Australia, Israel, Bulgaria, Slovakia and Luxembourg) aside, all the countries in the lower half are dominated by enterprise bargaining. This association also holds over time.

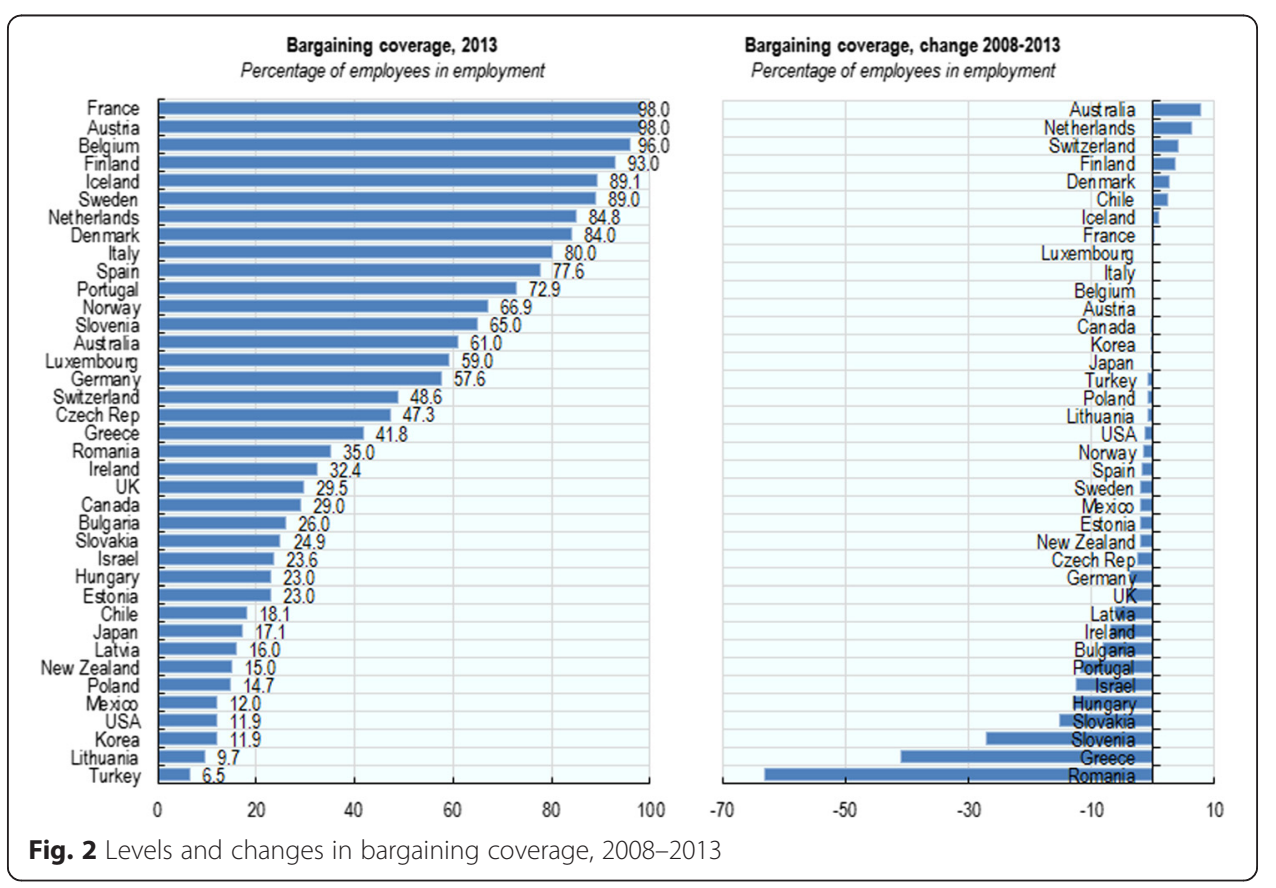


Wherever multi-employer bargaining breaks down and is replaced by singleemployer bargaining, the coverage rate decreases promptly and dramatically. Historical examples are the sharp decline in bargaining coverage after 1979 in Britain and after 1991 in New Zealand. Current illustrations are the sharp contraction of bargaining coverage in Romania and Greece following the termination of the national agreements in 2010 and the collapse of sectoral bargaining.

As shown in Fig. 2, right panel, the heaviest losses in bargaining coverage occurred in a subset of ten countries: Romania, Greece, Slovenia, Slovakia, Hungary, Israel, Portugal, Bulgaria, Ireland and Latvia. In each of these countries the decline in bargaining coverage was associated with, or caused by, regulatory change such as the discontinuation of national agreements and multi-employer bargaining, changes in the rules or policies on extension of sector agreements to nonorganized employers, and in the legal treatment of the validity of multi-annual and expired agreements. In Israel this has been part of a longer process that began with the dismantling of Israel-style corporatism far back in the 1970s and 1980smoving the country's industrial relations system closer to that of the USA than to Western Europe (Mundlak 2007).

In Germany, the UK, the USA and Japan the erosion of bargaining coverage during the Great Recession was the continuation of a process that had begun much earlier and was not related to regulatory changes during the crisis. Only in a few countries we see a counter trend; in Australia this may be due to regulatory change obliging employers to engage in bargaining under the Fair Work Act of 2010.

These cross-national differences in levels and changes illustrate that employers face different choices under company and sectoral bargaining. Under conditions of singleemployer bargaining employers may withhold or withdraw union recognition as a credible threat in seeking a cheaper or less constraining contract, or else relocate employment to a non-union environment. Newly established firms may refuse recognition to begin with and base the choice of where to invest on how easy it is to avoid unions. Union contracts tend to become associated with older firms and investments, and coverage and unionization rates decrease together with declining employment in older firms and sectors. Legally mandated union recognition procedures, based on elections in which workers must choose between offers from the union and threats issued by the employer, as in the USA and since 2000 in the UK, have done nothing to stop the erosion in bargaining coverage and union representation that results from this logic (Moore et al. 2014). ${ }^{6}$

When collective agreements apply to whole branches of the economy, employers who seek a change in the contract face different strategic options. They cannot easily escape collective arrangements by switching to a non-union environment, at least not when staying in the same sector and country. They can outsource activities to firms located in branches with cheaper collective agreements; make greater use of 'flexible employment'; discontinue membership in employers' associations; or work hard to obtain a change in the sector agreement, for instance transforming it into a framework for local negotiations. All of these strategies have been used and are visible in the data, but the overall impact on coverage rates is not a priori clear. For instance, outsourcing to cheaper contracts, or greater use of flexible employment, may be matched by an increase of collective bargaining activities and 
coverage of agreement in sectors such as cleaning, catering and security, and for agency work, part-time and fixed-duration employment, as has been the case in the Netherlands (Visser 2013).

\subsection{Extension}

Extension is an act of public policy based on explicit legislation mandating the government, a public agency or, in some cases, the court to apply the collective agreement beyond its signatories. Extension makes the normative provisions of the agreement mandatory for non-organized employers. It serves different purposes, such as the promotion of collective bargaining and self-regulation; the creation of common standards or funds for apprenticeships, training or pre-retirement; the enforcement of minimum wages and minimum terms of employment; and the binding of foreign service providers to domestic standards. Extension has been used for more than a century and the legal possibility of extending collective agreements exists in 28 of the 38 countries in this survey. However, the way in which extension operates - when and how, under what conditions, and to whom it applies - varies a great deal from nearly automatic and applied to nearly all agreements in France, Belgium, Spain, Austria, Finland, Slovenia, Greece (before 2010), Romania (before 2011) and Portugal (before 2011) to very selective, subject to representation thresholds and public policy tests like in Germany or Norway (see Table 1). The use of extension orders has declined continuously since the 1970s in Israel (Kristal and Cohen 2007), has been revived somewhat in Australia since 2010, is legally possible but not used in Japan and Korea, plays an important but declining role in supporting the few sectoral agreements that exist in CEE, and continues to play a large role in Western Europe, with the exception of Denmark and Sweden where no legal basis for mandatory extension exists. There are no legal extension mechanisms available in Canada, Chile, Denmark, Italy, New Zealand, Mexico, Sweden, Turkey, and the UK. In Italy, however, courts tend to honour minimum wage claims based on sectoral agreements for workers performing similar work.

Extension makes it less risky for employers to sign a sectoral collective agreement as it exposes them less to below-standard competition. For trade unions, extension cuts two ways (Flanagan et al. 1993:424): by eliminating the competition from low wage non-union firms or sectors, legal extension reduces the incentives for employer resistance to unions. It also reduces the incentives for consumers to shift purchases to the non-union sector and therefore increases union bargaining power. On the other hand, by providing for free what unions charge for, legal extension encourages 'free riders' among potential union members.

Since the Great Recession extension procedures have been changed in Greece, Ireland, Portugal, Romania, Estonia, the Czech Republic, Slovakia, Bulgaria, the Netherlands and Germany. In Greece, the Budget Law of 2011 suspended extension for the duration of the financial assistance measures, until 2015 or later. Unilateral recourse to arbitration, which usually helped trade unions to defend their case, was also struck from the law. Once non-member firms were no longer bound by the sector agreement, many took the opportunity to negotiate company agreements with less favourable provisions. After the change in government in May 2011, the Portuguese administration stopped issuing extension orders. Pressure from the Troika led to the 
Table 1 Extension regimes and direct coverage effects

\begin{tabular}{|c|c|c|c|c|}
\hline & \multicolumn{2}{|c|}{ Extension regimes } & \multicolumn{2}{|c|}{ Coverage effects } \\
\hline & 2008 & 2013 & 2008 & 2013 \\
\hline Austria & 3 & 3 & & \\
\hline Australia & 2 & 2 & & \\
\hline Belgium & 3 & 3 & $>15$ & $>15$ \\
\hline Bulgaria & 1 & 2 & & 1.5 \\
\hline Chile & 1 & 1 & & \\
\hline Czech Rep & 1 & 1 & 8.8 & 6.8 \\
\hline Estonia & 3 & 2 & 1.0 & 1.0 \\
\hline Finland & 2 & 2 & 11.9 & 16.0 \\
\hline France & 3 & 3 & $>20.0$ & $>20.0$ \\
\hline Germany & 1 & 1 & 0.4 & \\
\hline Greece & 3 & 0 & $>25$ & 0.0 \\
\hline Hungary & 1 & 1 & 6.5 & 2.5 \\
\hline Ireland & 1 & 0 & 4.0 & \\
\hline Israel & 1 & 1 & & \\
\hline Latvia & 1 & 1 & & \\
\hline Lithuania & 1 & 1 & & \\
\hline Luxembourg & 3 & 3 & & \\
\hline Netherlands & 2 & 2 & 9.1 & 9.1 \\
\hline Norway & 1 & 1 & 2.0 & \\
\hline Poland & 1 & 1 & & \\
\hline Portugal & 3 & 1 & $>25$ & \\
\hline Romania & 3 & 0 & & \\
\hline Slovakia & 2 & 1 & 6.0 & 0.0 \\
\hline Slovenia & 3 & 3 & 7.0 & 5.0 \\
\hline Spain & 3 & 3 & & \\
\hline Switzerland & 2 & 2 & 12.9 & 13.7 \\
\hline
\end{tabular}

Source: J Visser, ICTWSS database, version 5.0

Note:

extension regimes:

$3=$ virually automatic (most or all sectoral agreements)

$2=$ frequent and regular use, subject to majority thresholds

$1=$ limited use, subject to high thresholds, public policy test or veto power

direct coverage effects:

$\%$ of employees covered through extension only (not directly covered by collective agreement)

introduction of a quantitative threshold, similar to those in other countries; in order to qualify for extension the agreement must already cover half of the workers in the branch, geographical area or professional category (Ramalho 2013). The Portuguese economy is dominated by very small firms and with a 38 percent employment share of member firms in the private sector, employers' organization is low by European standards (Naumann 2015). The result has been a dramatic drop in both sectoral agreements and extension orders, from an average of 113 per year between 2000 and 2010, or 61 percent of all sectoral agreements concluded during these years, to 17 in 2011, 12 in 2012, 9 in 2013 and 13 in 2014..$^{7}$ The number of newly reached sectoral agreements had been declining since 2008 but dropped under 100 for the first time in 2011 with 36 new agreements in 2012 and just 27 in 2013. There was some recovery in sectoral 
bargaining in 2014 but the number of workers covered by newly concluded sectoral agreements, 215 thousand, is only a fifth of the number covered by newly reached agreements in 2010. Enterprise and 'group level' agreements register a similar sharp decline in recent times and the total coverage of new agreements has dropped to a mere 6.4 percent in 2013 from an average of 44.2 percent between 2000 and 2010. It is only through the coverage of older, still valid agreements, of which half are more than eight years old, that a coverage rate of about 70 percent is reached, but this begs the question as to how relevant these older agreements are in terms of (minimum) wage protection. The decline in bargaining activity at all levels suggests that the change in extension policy is not the only or perhaps not even the main cause, but that the dire economic conditions in many sectors and firms and uncertainty about government policies and regulatory changes may have prompted a standstill in bargaining (see for another interpretation Addison et al. 2015a). Whatever the role of extension, in 2014, after the rescue program finished, the government eased the criteria for extension: employers' organisations with 30 percent or more SMEs among their members can have their agreements extended even if they do not represent 50 percent of the sector's employees.

Romania's extension provisions were stopped by the 2011 Social Dialogue Act, which stipulates that sector agreements are applicable only to the members of the employers' organization(s) concluding them. In Ireland, decisions by the High Court in 2011 and the Supreme Court in 2013 found that Employment Regulation Orders and Registered Employment Agreements (REAs), which give binding effect to wage-setting mechanisms in some sectors, are unconstitutional (see also Regan 2013). The 1946 Industrial Relations Act was amended in 2015 to re-allow extension. Estonia has moved away from automatic extension, although applying to very few agreements. The procedure for triggering extension in Slovakia has been a source of controversy and was changed each time after elections. A 2007 law had removed the requirement that a nonorganized firm affected by extension orders must give its consent. This decision was reversed in 2010 and reinstated in 2014, after the change in government. The result was that there were no extension orders between 2011 and 2013. In the Czech Republic the law was amended in 2012 to provide for a provision that allows for the exemption of SMEs or firms in financial distress.

Going in the other direction, the Dutch government tightened in 2009 the rules under which firms can get exemptions from extension decisions. In order to qualify, the firm must not only negotiate a valid enterprise agreement with a bona fide union, but also show 'compelling reasons' why it should need derogation from the sector standard. In the period 2009-2014 about half the exemption requests, most of which are related to the extended agreements for agency workers, have been rejected. In some industries, for instance construction, the social partners award exemptions. In 2014, following the change in government, the German authorities took some measures, among which setting a threshold lower than 50 percent, intended to facilitate the uptake of extension procedures. In Bulgaria the government revived the 2001 law and issued three extension orders in 2009 but it did not stop the decline in sectoral bargaining in manufacturing. It is unclear whether the lowering of the representation threshold for trade unions in 2012 has had any effect. 


\subsection{Maximum validity of agreements and 'after effects' of expired agreements}

Procedures that influence the length of agreements and their validity beyond expiry also influence bargaining coverage. Such procedures tend to protect workers should employers refuse to negotiate and they strengthen the union negotiating position in case employers want to lower standards. The purpose of reforms of recent years has been to move unions to concession bargaining in times of recession.

In Greece the reform of 2012 replaced the possibility of indefinite collective agreements by a minimum validity of one and a maximum of three years (Dedoussopoulos et al. 2013). The 'after-effect' of expired agreements has been reduced from six to three months. If no new agreement can be concluded during this grace period, the expired agreement will cease to apply, except its terms on base salary, maternity, child, education and hazardous work allowances (ILO 2014). In Portugal, until 2003 a collective agreement could only be cancelled if all its signatory parties agreed or if replaced by an agreement between the same signatories. The 2003 reform introduced the possibility of expiry without replacement, which led to a sharp drop in bargaining activity and coverage. The law was revised in 2006 and further revision in 2009 introduced a reduction of the survival period to 18 months, reduced to one year in 2014. If the signatory parties agree to the inclusion of a special clause, the maximum duration permitted is since 2009 five, since 2014 three years. As there are fewer new agreements and many workers are covered only through older agreements, ${ }^{8}$ coverage will almost certainly fall sharply in years to come, unless there is a sharp uptake in bargaining. In Spain the 2012 reform ended the principle of indefinite extension of expired collective agreements and limits the 'after effect' of expired agreements to one year. If no agreement is signed, workers will be covered by a higher-level agreement if there is one. The coverage of agreements signed in earlier years remained high until 2012 but then dropped by between two and three million workers. ${ }^{9}$ Responding to union pressure, the central union and employers' associations agreed to advice their affiliates to use a speed track procedure to renew collective agreements. A 2012 law in Estonia replaces automatic continuation of agreements beyond expiry with the requirement that this should be agreed between the parties, like in Scandinavia where this is regulated under the basic agreement between central organizations.

\section{The vertical structure of collective bargaining}

Employer organization across firms, within sectors or regions, is a necessary condition for multi-employer bargaining. Associations must have the authority over and the mandate from member firms to negotiate an agreement with the union(s) and bind its member firms to its terms. Employers in most Western European countries have since 1945 organized for the purpose of bargaining, usually at the sectoral level, as a strategy to keep distributional conflict away from the workplace and wages out of competition (Sisson 1987). Organization rates, measured as the share of employees working in member firms of employers' associations, vary from about 40 percent in Greece and Portugal to 80 percent or more in the Netherlands, Sweden or Finland. Unfortunately, there are no reliable data for the non-European countries.

In the post-communist countries of Central and Eastern Europe (CEE) employers' associations had to be created after 1989 and outside the (former) state sector this 
has been exceedingly difficult, resulting in a rather weak and highly fragmented set of organizations often incapable of extracting a mandate from their members (Bohle and Greskovits 2012; Kohl and Platzer 2004). Sectoral agreements remain exceptional, unstable and fragmented. Slovenia has been the exception; until the law was changed in 2005 Chambers of Business with compulsory membership signed collective agreements, thus assuring a bargaining coverage rate of hundred percent. The organization rate of employers, based on voluntary membership, has since dropped to about 60 percent, which is still much higher than elsewhere in the region.

Outside Europe, employer organization for the purpose of bargaining is less common. In New Zealand and Australia such organizations have been involved in bargaining both at the national and sectoral level, but their role as bargaining agent has been reduced in the 1990s. There are powerful business associations and in some countries, for instance in Japan, they are involved in coordinating annual rounds of wage bargaining, but sectoral employers' associations are the exception. In Japan, the Republic of Korea, Turkey after the military coup of 1980, Mexico since the 1980s and in postPinochet Chile the political and legal framework is set for enterprise bargaining in spite of union attempts to establish industry bargaining in some industries, for instance road transport in Chile or banking in Korea. In Israel, where the last national agreement was signed in 1987, the influence of national union and employers' federations, and sectoral agreements, has been declining since (Kristal and Cohen 2007; Mundlak 2007). When American and Canadian employers practiced multi-employer bargaining it was on a local basis. Flanagan (1993: 49) calls the collapse of local or regional multi-employer agreements in the first half of the 1980s "the most dramatic change in official bargaining structures" in the USA since the 1930s New Deal policies. The Canadian experience was broadly similar, though compared with their US colleagues, "Canadian managers appear to have been less aggressive in seeking non-union options over this period of time" (Kochan and Verma 1992: 198).

Table 2 shows the scope and distribution of single-employer (enterprise) and multi-employer (sector, region, national) bargaining since 2000. The first thing to note is that where single-employer bargaining prevails only a minority of workers has access to collective bargaining. Usually these are the workers employed by larger firms, in parts of mining and manufacturing and in the privatised utility sector (post office, railways, airlines, telecommunication, et cetera), and, unless barred from collective bargaining, in public administration, heath and education. Only in the 14 countries with multi-employer bargaining does collective bargaining reach the majority of workers.

In Greece, Romania, the Czech Republic, Slovakia, Bulgaria and Ireland multiemployer bargaining all but disappeared during the recession. But even in the countries of continental North-West Europe where multi-level bargaining seems stable much has changed and more issues are now negotiated or decided at firm level, as I will discuss below. It is to be stressed, however, that although more enterprise agreements are signed compared to ten or fifteen years ago, their weight in terms of employees covered has not. Company bargaining received a boost after the privatisation of former state companies in the 1980s and 1990s, but there are few cases of sectoral agreements breaking up in firm-level agreements, after the UK example in the 1980s. In Denmark 
Table 2 Single- and multi-employer bargaining, 2000-2013

\begin{tabular}{|c|c|c|c|c|c|c|c|c|c|}
\hline & \multicolumn{3}{|c|}{$\begin{array}{l}\text { Single-employer } \\
\text { bargaining }\end{array}$} & \multicolumn{3}{|c|}{$\begin{array}{l}\text { Multi-employer } \\
\text { bargaining }\end{array}$} & \multicolumn{3}{|c|}{$\%$ share of single-employer bargaining } \\
\hline & 2000 & 2008 & 2013 & 2000 & 2008 & 2013 & 2000 & 2008 & 2013 \\
\hline United States & 14 & 13 & 12 & 1 & 1 & 1 & 93 & 96 & 96 \\
\hline Canada & .. & 26 & .. & .. & 3 &.. & .. & 90 & .. \\
\hline Mexico & .. & .. & 11 & .. & .. & 1 & .. & .. & 90 \\
\hline Chile & & 14 & 15 & & 3 & 3 & .. & 84 & 83 \\
\hline Japan & 23 & 19 & 18 & 1 & 1 & 1 & 96 & 95 & 95 \\
\hline Rep of Korea & 12 & 11 & 11 & 1 & 1 & 1 & 90 & 92 & 91 \\
\hline Turkey & 9 & 6 & 6 & 3 & 1 & 1 & 76 & 86 & 85 \\
\hline Israel & 18 &. & 20 & 38 & .. & 6 & 32 &. & 77 \\
\hline United Kingdom & 29 & .. & 28 & 7 & .. & 4 & 81 & .. & 88 \\
\hline New Zealand & 16 & 14 & 13 & 4 & 3 & 2 & 80 & 82 & 87 \\
\hline Australia & 12 & .. & 28 & 48 & .. & 25 & 20 & .. & 53 \\
\hline Ireland & 0 & 0 & 27 & 44 & 41 & 5 & 0 & 0 & 84 \\
\hline Lithuania & 15 & 14 & 9 & 0 & 0 & 1 & 100 & 100 & 90 \\
\hline Estonia & .. & 17 & 19 & .. & 7 & 4 & .. & 71 & 83 \\
\hline Latvia & .. & .. & 12 & .. & .. & 3 & .. & .. & 80 \\
\hline Poland & .. & 13 & 12 & .. & 3 & 3 & .. & 81 & 80 \\
\hline Hungary & 29 & 27 & 20 & 5 & 11 & 6 & 85 & 71 & 77 \\
\hline Czech Republic & $85^{\mathrm{a}}$ & 27 & 33 & 12 & 24 & 15 & $74^{\mathrm{a}}$ & 53 & 69 \\
\hline Slovak Republic & 21 &. & 17 & 16 & .. & 8 & 57 & .. & 68 \\
\hline Romania & .. & 25 & 32 & & 70 & 3 & & 26 & 91 \\
\hline Greece & .. & 10 & 30 & .. & 75 & 10 & .. & 12 & 75 \\
\hline Luxembourg & 29 & 24 & .. & 36 & 35 & .. & 45 & 41 & 41 \\
\hline Denmark & .. & $22 c^{b}$ & .. & .. & $62 c$ & .. & .. & $26 c^{b}$ &. \\
\hline Norway & .. & .. & .. & .. & .. & .. & .. & .. & $<20$ \\
\hline Switzerland & 9 & 9 & 8 & 36 & 37 & 41 & 20 & 20 & 16 \\
\hline Sweden & $13^{\mathrm{b}}$ & .. & & 75 & .. & & $15^{\mathrm{b}}$ & .. & $<15$ \\
\hline Germany & 8 & 9 & 8 & 61 & 53 & 50 & 12 & 14 & 14 \\
\hline Finland & .. & 10 & 10 & .. & 78 & 80 & .. & 11 & 11 \\
\hline Netherlands & 11 & 7 & 9 & 71 & 71 & 76 & 13 & 9 & 11 \\
\hline Portugal & 13 & 3 & 7.5 & 69 & 70 & 60 & 4 & 4 & 11 \\
\hline Italy & .. &. & & .. &. & .. &. & .. & $<10$ \\
\hline Spain & 10 & 8 & 7 & 73 & 72 & 71 & 12 & 10 & 9 \\
\hline Slovenia & 0 & 1 & 5 & 96 & 91 & 71 & 12 & 10 & 9 \\
\hline Belgium & .. & 5 & 5 & .. & 90 & 90 & .. & 5 & 5 \\
\hline Austria & 3 & 3 & 3 & 95 & 95 & 95 & 3 & 3 & 3 \\
\hline France & $2 a$ & 2 & 2 & $91 a$ & 96 & 96 & $2 a$ & 2 & 2 \\
\hline
\end{tabular}

Source: J. Visser, ICTWSS database, version 5.0

..: Not available

$a=$ overlap with multiple employer agreements

$\mathrm{b}=$ mainly 'extension' or 'application' agreements, applying sector rate

and Sweden separate enterprise agreements, called 'adhesion agreements', are signed by unorganized firms under union strike pressure in order to widen the scope of sector agreements, not as its alternative. 


\subsection{Central or cross-industry bargaining}

Decentralisation has been the main trend in industrial relations since the 1980s-reversing the long-term trend of previous decades, which reached its apex during the energy and currency upheavals of the 1970s when many countries tried to respond to wage cost pressures with incomes policies based on central agreements and tripartite social pacts (Addison 1981; Armingeon 1982; Flanagan et al. 1983). Central, cross-industry wage agreements ended in the late 1970s or early 1980s in Austria, Denmark, the Netherlands, Spain and Sweden, some time later in Norway and, in the form of central award setting, in New Zealand and Australia in the 1990s. They continued in Finland, Belgium and Greece, usually with much help or pressure from the government. Tripartite social pacts and agreements became the format for wage setting in Ireland from 1987 to 2009, during some years in the 1980s and 1990s in Portugal, from 1994 in Slovenia and from 2005 in Romania. There never were central wage agreements in Germany, Switzerland, the UK, Canada, the USA, Japan and the other non-European countries. The UK went through a phase of union-government 'social contract' bargaining in the 1970s, and there were similar social pacts in Australia in the 1980s, in South Korea during the Asian crisis (1997) and in Chile after the end of dictatorship in 1990. There were sparse pacts in CEE and the tripartite social dialogue over the national minimum wage, introduced in many CEE countries during or after transition, sometimes served as an Ersatz for wage negotiations based on bargaining power of employers and unions. Political and social considerations were often preponderant, but employers could retaliate by not complying and payment below the minimum or re-arranging employment contracts in works contracts outside the scope of minimum wage laws was a widespread practice (EC 2004).

In 2008, at the beginning of the recession, there were still five countries with central cross-industry pay bargaining: Belgium, Greece, Ireland, Slovenia, and Romania. In these countries the central agreement contained a precise figure for minimum (Greece, Romania, Slovenia), standard (Ireland,) or maximum (Belgium) pay rises to be detailed in sectoral and enterprise-level negotiations. In Finland the central incomes policy agreement had ended a year earlier. In Spain the national agreement sets a framework for sectoral bargaining, but does not recommend a specific pay rise.

During the recession central pay bargaining ended in Ireland (1987-2009), Greece (1990-2010) and Romania (2005-2010) and in these three countries enterprise-level bargaining now prevails. The cross-sectoral agreement in Slovenia, which applied to sectors and companies not covered by sectoral collective bargaining, was not renewed in 2009 when it expired. There are now fewer sectoral agreements and in two sectors, chemicals and construction, employers unilaterally cancelled the sectoral agreements in 2013. A new national cross-industry agreement was signed in 2015, but its provisions deal with non-wage issues only. In Greece the two general agreements signed since 2010, the first without support from the main private sector employers' federation, are rather symbolic and contain no provisions on (minimum) wages. In Finland, on the other hand, central pay bargaining resumed in 2011 after an interlude of four years of sectoral and company bargaining. As in Belgium, where the government imposed the biennial central 
agreements of 2011 and 2013, the government's approach was decisive in reviving (Finland) or ending (Greece, Romania) central-level bargaining. In Ireland and Slovenia employers pulled out.

\subsection{Indexation}

Automatic indexation of wages to prices is a proxy for centralisation. This method has survived only in Belgium and Luxembourg. Clauses in collective agreements with automatic indexation mechanisms triggering wage rises have been abolished in the USA (around 1980), New Zealand and Australia (1980s), Denmark (1983), the Netherlands (1983), Switzerland (1991), Italy (1992), and Sweden (1993). Against the specific recommendation under the EU's new economic governance system, the Belgian government decided in 2012 to retain automatic wage indexation with some adjustments in the calculation. The latest central agreement for 2013-14 allows wages to rise only as much as the change in the cost-of-living index. In Luxembourg, which received a similar EU admonition, the government failed to gain union support for reform in 2010 and went ahead unilaterally with suspending indexation between 2012 and 2014 .

In Spain, pay guidelines based on inflation forecasts in the cross-sectoral agreements since 2002 in combination with the wage revision clauses in sectoral agreements which adjust wages to observed inflation operate as a form of 'soft' or 'non-automatic' indexation. In Italy, the cross-sector agreement of 2009 has adopted more or less the same model, whereas previously, based on the triparite reform pact of 1993, past inflation had been the basis for wage adjustments in sectoral agreements. In Spain, meanwhile, there has been a sharp decline in the use of revision clauses. With no cross-industry agreement signed in 2009, the new biennial central framework agreements reached in 2010 and 2012 no longer incorporate official inflation forecasts. Probably reflecting this, the proportion of employees covered by collective agreements with wage revision clauses fell from two-thirds in 2007, prior to the crisis, to an estimated one-third in 2012.

\subsection{Sector or industry-level bargaining}

During the Recession industry-level bargaining came under pressure in many countries and in some it ended. There is no sectoral or other multi-employer bargaining framework in Ireland except in construction and some parts of the hotel business. Company level bargaining takes place in the unionised sectors of the economy, which is predominately made up of traditional industry and the semi-state sectors (Erne 2011, Regan 2012). In Greece the general agreement used to be detailed in a few hundred sectoral and occupational agreements. Dedoussopoulos et al. (2013) cites Ministry data showing that by May 2013 out of a total of 272 occupational or sectoral agreements existing in 2010233 had been terminated and only 33 were renewed (6 were unaccounted for). The number of enterprise agreements soared from a handful to 976 in 2012, only 27 percent of which were signed by the unions (Ioannou and Papadimitriou 2012).

In Spain bargaining activity peaked in 2008 with nearly 6,000 collective agreements applying to 12 million workers. Both sector and company agreements went into decline to a total of 4,374 in 2012 before rising to almost 4,600 agreements in 2013. More than half of these agreements had been concluded before 2013. New agreements dropped by 
almost one thousand from 2,145 in 2008 to 1,183 in 2011 before recovering in 201314. In Portugal the dramatic decline in sectoral bargaining can be attributed to the severity of the crisis, the stop in extension orders, the uncertainty of reforms, and the divisions among unions and between unions and employers. There was hardly any agreement renewed in manufacturing and the construction agreement lost half its size. Nor were there, contrary to Greece, signs of a replacement of sector by enterprise bargaining. In fact, the number of enterprise agreements fell from 61 in 2010 to 29 in 2013 before rising to 80 in 2014, covering just 12,400 employees, down from 33,000 in 2010.

In Italy and France, too, there were long delays in renewing existing agreements. According to data from the national statistical office, early 2014 more than half of all workers in Italy's private sector were waiting for a new agreement and the mean delay in contract renewal had increased to 12 months (almost 24 months in the cashstrapped public sector). ${ }^{10}$ Ministry data in France, early 2014, showed a 30 percent drop in the number of (national and regional) sector agreements compared to the year before. ${ }^{11}$ Already in 2011 a Ministry study complained that many (regional) sector agreements were characterized by "une ancienneté forte et une activité conventionnelle peu dynamique". ${ }^{12}$ In Germany and the Netherlands the problems with renewing agreements also showed, especially when the recession ended and employers offered resistance to higher wages demanded by the unions after years of austerity. In Belgium there was a marked decline in sectoral agreements concluded under the latest central agreement, presumably because there was nothing left to bargain over.

In CEE, already before the recession, sectoral bargaining was the exception rather than the rule. Under communism, wage setting had been characterized by central controls amended by informal bargaining within the enterprise. After 1989 enterprise bargaining within the state sector replaced informal bargaining and had some tradition to build on. In stead, sectoral bargaining had to tread entirely new grounds. The new post-1989 labour laws preparing the ground for free collective bargaining did in most CEE countries introduce the concept of multi-employer agreements but in the absence of employers' organization the agreements that were concluded did rarely cover an entire sector, often contained no wage clause and did not set effective wage floors.

In Romania no sectoral collective agreements have been signed since 2011 besides a handful of agreements combining specific company groups. In Bulgaria, the previous trend of sector agreements in manufacturing to be replaced by company agreements accelerated after 2008, when employers stopped negotiating at the sector level in chemicals, electrical equipment and food processing. According to a state inspectorate's report collective bargaining in Poland is now rare in the private sector, with hardly any sectoral bargaining. During the recession sectoral bargaining further weakened to the point of near extinction in the private sector in Lithuania and Latvia. Gonser (2011) in a review of developments during the current crisis in the three Baltic states, claims that governments have de-legitimized collective bargaining as an institution by walking away from the agreements they had signed as employer. In Slovakia sector agreements used to be fairly widespread, but their number and coverage have declined in recent years, with employers withdrawing from their organizations. Kézdi and Kónya (2011), using an establishment survey, affirm that sector bargaining in the private sector has become rare in Hungary. In the Czech 
Republic since 2008 fewer collective agreements stipulate a specific year-on-year wage increase; in 2010 such rate increases were agreed in less than half of all agreements. Even in Slovenia, where multi-employer bargaining is more established, during the recession breaches of the pay guarantees in sectoral agreements soared from 462 reported cases in 2007 to 2,596 in 2010, followed by a slowing down, or even full stop, of the renewal of agreements.

\subsection{Decentralisation and articulation of multi-level bargaining}

In the context of this paper I define decentralisation as moving negotiations and decisions over wages and terms of employment closer to the individual enterprise. Decentralisation occurs when central or sectoral agreements are articulated with or replaced by enterprise agreements. This occurs either through the breaking up of sectoral or national agreements when employers stop negotiating jointly and some or all of them negotiate an enterprise-level agreement. Or decentralisation happens through a process of articulation or devolution within the central or sectoral agreement when more issues are settled at lower levels (Guigni 1965; Crouch 1993). Traxler (1995) has coined the movement of retaining sectoral (or central) bargaining with more room for additional enterprise bargaining 'organized decentralisation', which he has contrasted with 'disorganized decentralisation' when national or sectoral agreements are ended.

The first step in measuring decentralisation of pay bargaining is to establish at which level most bargaining takes place: central, industry or sector, or company. For this I use a five-point scale allowing for two intermediary situations when bargaining levels alternate between years or it is impossible to assess which of the two nearest levels contributes more to actual regulation of employment relations (see OECD 2004). A particular level is dominant if it accounts for at least two-thirds of bargaining in terms of employees covered (as shown in Table 2). Measured on this scale the mean trend of decentralisation of wage bargaining is clearly confirmed (Fig. 3). It started in the 1980s, intensified in the 1990s, stayed level during the decade preceding the crisis and received a boost during the crisis due to the end of central-level and sectoral bargaining

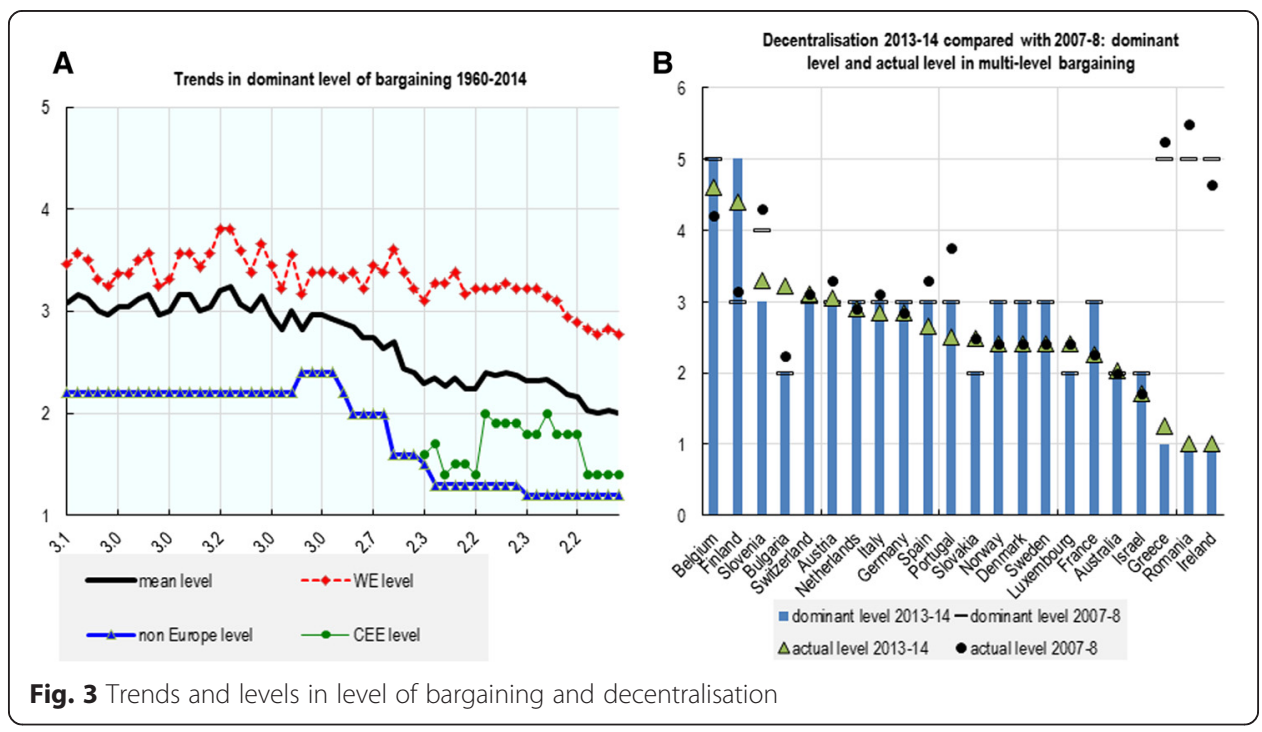


in some countries. Among the non-European members of the OECD and in CEE multi-level bargaining at any level above the company has all but disappeared. What has happened is mostly disorganized decentralization and most of it happened already one or two decades before the Great Recession.

The second step is to take into account the frequency and diffusion of local (enterprise) bargaining, the articulation between sectoral and enterprise bargaining, and the existence and use of general derogation clauses or 'open' (framework-type) agreements that leave actual wages to be decided at enterprise level. According to the European Company Survey of 2009, in EU countries with a dominant role for sector or central agreements, just under half of the employees covered by collective agreements fell under sector agreements with some form of additional firm-level bargaining or paysetting. This describes the situation in manufacturing and larger firms rather than in services and small and medium-sized firms. Such additional bargaining can operate in different ways: (a) it is common, limited to large firms, or rare; (b) it is articulated and under control of the the same union(s) that negotiate the sector agreement or it is unarticulated, either because it is disallowed legally or involves actors other than the unions negotiating the sector agreement; (c) derogation from sectoral standards is defined by law, fully or partly disallowed, or a matter to be decided by the contracting parties themselves; and (d) sectoral agreements do or do not contain a general opening clause on wages or working hours to be negotiated at lower levels and with outcomes that deviate, upwards or downwards, from sectoral standards. Together and combined with the dominant level at which bargaining takes place these variables define the actual level of wage bargaining or decentralisation (see Table 3 ). ${ }^{13}$

Countries with the same dominant level of bargaining do vary a great deal on these indicators (frequency or scope of additional enterprise bargaining; articulation; legal status of derogation; existence and use of general opening clauses) and thus in actual decentralisation (Fig. 3, right panel). In Scandinavia, local bargaining within the currency of the sectoral agreement is common (Calmfors 1990), is under union control and the enterprise has become the main location for pay-setting in the entire private sector. In Germany and France additional enterprise bargaining is common in large firms, controlled by works councils rather than the union, and shaped by specific and conditional opening clauses. Such opening clauses have also figured in Austrian bargaining over wages and working hours, though they were not widely used. Individual bargaining and choice menus have shaped derogation from sectoral standards in the Netherland and Switzerland (Mach and Oesch 2003; Visser 2013). In Belgium and recently in Finland this development has affected issues other than wages, which tend to be specified standard or maximum rates defined through central agreements. In France, Southern Europe and CEE actual decentralisation happened by means of regulatory intervention, before (France, Hungary) and during (Greece, Portugal, Italy, Spain, Romania) the recession, and in some of these countries at the price of considerable disarticulation due to the legal recognition of non-union actors as counterparts in enterprise bargaining. One main reason for this difference is that in Scandinavia, the Netherlands and Switzerland, as in the UK and Ireland, the hierarchy between agreements, and the favourability principle holding that in case of conflict the first established or most favourable agreement applies is a matter of agreement and not of the law. 
Table 3 Dominant bargaining level and actual level of bargaining

\begin{tabular}{|c|c|c|c|c|c|c|c|c|}
\hline & \multicolumn{4}{|c|}{ Dominant bargaining level } & \multicolumn{4}{|c|}{ Actual level of bargaining } \\
\hline & 1990-91 & 2000-01 & $2007-8$ & $2013-14$ & 1990-91 & 2000-01 & $2007-8$ & 2013-14 \\
\hline Finland & 5.0 & 4.0 & 3.3 & 4.5 & 5.2 & 4.0 & 3.2 & 4.4 \\
\hline Norway & 4.0 & 4.0 & 3.0 & 3.0 & 3.7 & 3.7 & 2.4 & 2.4 \\
\hline Sweden & 4.0 & 3.0 & 3.0 & 3.0 & 3.7 & 2.4 & 2.4 & 2.4 \\
\hline Denmark & 3.0 & 3.0 & 3.0 & 3.0 & 2.7 & 2.4 & 2.4 & 2.4 \\
\hline Germany & 3.0 & 3.0 & 3.0 & 3.0 & 3.6 & 3.1 & 2.9 & 2.9 \\
\hline Austria & 3.0 & 3.0 & 3.0 & 3.0 & 3.6 & 3.3 & 3.3 & 3.1 \\
\hline Netherlands & 3.0 & 3.0 & 3.0 & 3.0 & 3.4 & 3.0 & 2.9 & 2.9 \\
\hline Belgium & 4.5 & 4.5 & 4.5 & 5.0 & 4.2 & 4.2 & 4.2 & 4.6 \\
\hline Luxembourg & 2.0 & 2.0 & 2.0 & 2.0 & 2.4 & 2.4 & 2.4 & 2.4 \\
\hline Switzerland & 3.0 & 3.0 & 3.0 & 3.0 & 3.4 & 3.1 & 3.1 & 3.1 \\
\hline France & 3.0 & 3.0 & 3.0 & 3.0 & 3.1 & 2.7 & 2.3 & 2.3 \\
\hline Italy & 2.0 & 3.0 & 3.0 & 3.0 & 2.1 & 3.2 & 3.1 & 2.9 \\
\hline Spain & 3.0 & 3.0 & 3.0 & 3.0 & 3.5 & 3.3 & 3.3 & 2.7 \\
\hline Portugal & 4.0 & 3.0 & 3.0 & 3.0 & 4.8 & 3.8 & 3.8 & 2.5 \\
\hline Greece & 5.0 & 4.5 & 4.5 & 1.0 & 5.8 & 5.3 & 5.3 & 1.3 \\
\hline UK & 2.0 & 1.0 & 1.0 & 1.0 & 1.7 & 1.0 & 1.0 & 1.0 \\
\hline Ireland & 5.0 & 5.0 & 5.0 & 1.0 & 4.7 & 4.7 & 4.7 & 1.0 \\
\hline Estonia & 1.0 & 1.0 & 1.0 & 1.0 & & 1.0 & 1.0 & 1.0 \\
\hline Latvia & 1.0 & 1.0 & 1.0 & 1.0 & & 1.0 & 1.0 & 1.0 \\
\hline Lithuania & 1.0 & 1.0 & 1.0 & 1.0 & & 1.0 & 1.0 & 1.0 \\
\hline Poland & 1.0 & 1.0 & 1.0 & 1.0 & & 1.0 & 1.0 & 1.0 \\
\hline Slovenia & & 2.0 & 2.0 & 2.0 & & 2.5 & 2.5 & 2.5 \\
\hline Hungary & 2.0 & 1.0 & 1.0 & 1.0 & 2.2 & 1.0 & 1.0 & 1.0 \\
\hline Czech Rep & 2.0 & 1.0 & 1.0 & 1.0 & 2.4 & 1.0 & 1.0 & 1.0 \\
\hline Slovenia & 3.0 & 4.0 & 4.0 & 3.0 & 3.3 & 4.3 & 4.3 & 3.3 \\
\hline Bulgaria & & 2.5 & 2.0 & 2.0 & & 2.8 & 2.2 & 2.2 \\
\hline Romania & & 3.0 & 5.0 & 1.0 & & 5.5 & 5.5 & 1.0 \\
\hline Canada & 1.0 & 1.0 & 1.0 & 1.0 & 1.0 & 1.0 & 1.0 & 1.0 \\
\hline USA & 1.0 & 1.0 & 1.0 & 1.0 & 1.0 & 1.0 & 1.0 & 1.0 \\
\hline Mexico & 1.0 & 1.0 & 1.0 & 1.0 & 1.0 & 1.0 & 1.0 & 1.0 \\
\hline Chile & 1.0 & 1.0 & 1.0 & 1.0 & 1.0 & 1.0 & 1.0 & 1.0 \\
\hline Australia & 4.0 & 2.0 & 2.0 & 2.0 & 4.1 & 2.0 & 2.0 & 2.0 \\
\hline New Zealand & 3.0 & 1.0 & 1.0 & 1.0 & 3.1 & 1.0 & 1.0 & 1.0 \\
\hline Japan & 1.0 & 1.0 & 1.0 & 1.0 & 1.0 & 1.0 & 1.0 & 1.0 \\
\hline Korea & 1.0 & 1.0 & 1.0 & 1.0 & 1.0 & 1.0 & 1.0 & 1.0 \\
\hline Israel & 2.0 & 2.0 & 2.0 & 2.0 & 2.7 & 2.7 & 1.7 & 1.7 \\
\hline Turkey & 1.0 & 1.0 & 1.0 & 1.0 & 1.0 & 1.0 & 1.0 & 1.0 \\
\hline
\end{tabular}

Source: J. Visser, ICTWSS database, version 5.0

Lack of articulation has been a recurrent theme in the literature on collective bargaining in Spain, Portugal, Greece and France. Costa (2012:405) notes juridification, excessive competition among unions, lack of self-regulation and recurrent state intervention as impediments to collective bargaining in Portugal. Xavier (2004:194-5) finds collective bargaining incoherent "because these forms of bargaining (i.e. interprofessional, 
sectoral, regional or company, auth.) are not articulated". According to Barreto (1992:471), "the tension between an over-regulated and highly legalistic framework and voluntary collective bargaining may help explain why formal company bargaining is so rare in the private sector, and why industry bargaining has so little impact on working conditions and terms of employment in leading or even average enterprises." He sees this as a legacy of the state-corporatist regime, which compensated the repression of unions and limitations on collective bargaining by legalistic rules of protection. The legal reform of 2009 introduced the possibility that in firms of 500 and more staff, the works councils negotiate enterprise agreements that override the standards set in sector agreements. In the Memorandum of Understanding with the Troika, signed in 2011, the threshold was lowered to 250 and in the Labour Code of 2012 to 150. The suggestion of the Troika to strike the unions' veto from the law was not taken up and works councils can only sign agreements when unions allow it. The 2012 reform specifies that provisions of enterprise agreements take priority over those contained in sector agreement unless employers and trade unions insert a clause to the contrary in sectoral agreements. Note that according to the European Company Survey of 2009, Portugal, along with Greece and some countries in CEE, had the weakest and least diffused system of works councils in the EU.

The problem of disarticulated agreements, and the same legacy, has also beset postFranco Spain. Pérez-Díaz and Rodrigues (1995: 180) classify the Spanish bargaining system as unarticulated; provincial-based industry bargaining did neither create incentives nor set a floor for enterprise bargaining. In 1994 there was a push towards replacing the old statutes by a more dynamic system. For different reasons unhappy with that reform, the central union and employers' organisations signed in 1997 an agreement on collective bargaining with the tacit goal of avoiding further government intervention (García Blasco and de Val Tena 2004:217). This agreement followed the union preference for a multi-level bargaining structure with limited devolution to the company level. The fact that unions are only represented in larger firms (Beneyto 2008) made them very reluctant to endorse devolution. The reforms of 2011 and 2012 tried to reverse the order: both wages and pay supplements should be set at company level, whereas non-pay issues could be dealt with in sector agreements. To this end, the 2012 reform allows enterprise agreements to regulate all issue irrespective of what higherorder agreements stipulate. In case of disputes, when works councils want to retain sectoral norms, the law prescribes mandatory arbitration, thus limiting the autonomy of the social partners. In Spain works councils are well established in larger firms and unlike for instance works councils in Germany they have a legal mandate to negotiate collective agreements on wages.

Greece's collective bargaining has been described as centralized, unarticulated and shallow, with various levels of bargaining co-existing but each level having a low capacity of regulation (Koukiadis 2009). The content of agreements is poor, mainly dealing with remuneration and allowances (Yannakourou and Soumeli 2004). Enterprise bargaining outside the state sector has been rare (Zambarloukou 2006). This has dramatically changed, however. The Memorandum of Understanding with the EU/ECB/IMF and the 2011 law for implementation of the Medium-term Budgetary Strategy Framework 2012-2015 provides for the possibility of 'association of persons' representing a minimum of 60 percent of the company's staff to negotiate enterprise agreements, with the possibility to set wages at a lower level than provided in sector-level and 
occupational agreements. ${ }^{14}$ This established a bargaining circuit outside the control of unions and contested by them.

Until the early 1980s industry bargaining remained dominant in France, though reforms to make its role more important failed (Saglio 1995). The socialist's government's reforms of 1982-83 shifted the locus of bargaining to the enterprise, making it obligatory for employers to negotiate working hours changes and instituting direct employee representation in the enterprise. Successive governments have since promoted the enterprise level as a conduit for public policy interventions, further enhancing the autonomy of the enterprise from the wider industrial relations system, together with a relocation of employee representation from the trade union to non-union, firm-specific institutions in all but the largest firms (Jobert and Saglio 2005). In 1995 three of the six French union confederations reached an agreement with employers authorizing a mandated non-union representative to sign an enterprise agreement on working time. According to Howell and Kolins Givan (2011:243) this was a post hoc legitimization of a practice that had evolved since the 1980s. "A set of legal exemptions first introduced in the 1980s steadily eroded the primacy of the industry level, capped by a 2004 law on social dialogue which reinforced the autonomy of firm-level negotiators in almost every domain save wages."(Culpepper 2006:37). Saglio (1995:210) claims that unions and employers' associations have often allowed poor enforcement of industry agreements from which "exceptions are now often permitted as a means of reducing unemployment". This development was sanctioned by the legal reform of 2004 which privileged standards negotiated at company level over those specified in sector agreements on a range of issues except the statutory minimum wage and job classification. Under certain conditions trade unions, if gaining a majority in works council elections, can invalidate the results (Keune 2011). Prepared by another central agreement, signed by three of the six main confederations, the 2008 legal reform makes it possible to negotiate agreements in smaller firms where there is no trade union presence. What has evolved is a disconnected dual system. In large industrial firms and in the public sector, where French trade unions still maintain a presence, the typical deal was to exchange working time flexibility and increased productivity for job security; in small firms and low-skill service sectors, without union representation, working arrangements and employment conditions appear to have deteriorated and external flexibility increased, without a trade-off (Lallemand 2006; Palier and Thelen 2010).

In more countries, Lithuania, Hungary, Romania, more recently in Greece, recent legal reforms confer negotiating rights on works councils and non-union bodies in lieu of trade unions. In Portugal the government, warned by the Constitutional Court, stepped back from removing the union veto. But it is clear that in all these countries, and in Spain, recent governments, encouraged by their international advisers, have pushed for enterprise bargaining in stead of sectoral bargaining and that removing the union monopoly over wage bargaining is part of that push. The 2011 Social Dialogue Act in Romania makes collective bargaining mandatory in enterprises of 20 and more workers. The criteria for trade unions to secure representativeness status as a precondition for negotiating valid agreements at sector and company levels have been tightened and where unions do not meet these criteria employers can negotiate with elected non- 
union employee representatives. In Hungary, the conservative government removed in 1998 the exclusive prerogative of unions to negotiate collective agreements and introduced a legal provision allowing works councils to sign collective agreements in the absence of union organization in the workplace. The provision was little used and repealed in 2002, but reinstated in 2012 when Orbán was re-elected.

\section{Temporary opening clauses}

Temporary opening or 'inability to pay' clauses have become rather popular during the Recession. They are to be distinguished from the general derogation clauses discussed in the previous paragraph. General derogation clauses delegate particular issues to be decided at enterprise level under conditions specified in the sector agreement and with outcomes that can deviate from sectoral minima or standards. In the limit case, as in some sector agreements in manufacturing in Sweden, Denmark, Switzerland and the Netherlands the sector agreement does not specify (minimum) pay provisions. Temporary 'inability to pay' clauses allow the suspension or renegotiation of (part of) the agreement in cases of hardship, although how tightly this is defined varies. General opening or derogation clauses are an instrument of organized decentralisation within sectoral agreements; they have no place in enterprise agreements. Temporary hardship clauses can apply to any collective agreement at any level and rather being an element of decentralisation they are a safety valve in agreements that define hard minimum or standard conditions, and in agreements that cover a period longer than one year.

The German case is an illustration of how something that began as a temporary local solution for firms to survive and for employees to rescue their jobs can become institutionalised as a permanent extra layer in collective bargaining. Formally, under par 4 of the German law on collective bargaining deviations from the sectoral standards set in collective agreements are only allowed when the bargaining partners explicitly make a provision for them. Informally, however, informal 'pacts' between works councils and management, began to spread not long after 1990 (Kädtler 2003; Streeck 2009; Ellguth and Kohaut 2008). Payment below the sectoral norm was practiced by about one-third of all firms (Schnabel 1995:70). Attempts to move to broad framework agreements and leave implementation to local bargaining failed. Only around 2004 the metalengineering union and the union in the chemical industry signed sector agreements in which they conceded the use of opening clauses under particular conditions and supervised at the sectoral level. According to the IAW collective agreements database about half of all firms under collective agreements have recourse to opening clauses, though far fewer use them (Heinbach 2005). Addison et al. (2015b), using the IAB panel survey, report that up to 40 percent of all firms under collective agreements have recourse to opening clauses, whereas up to 70 percent, in 2011, responded that they have used these clauses. According to the IAW collective agreements database about one third of the opening clauses are about pay and half are about working time (Brändle and Heinbach 2010). Most clauses are restricted in time and many rely on an agreement with the union (metal-engineering) or the works council (chemical industry). Haipeter (2013) argues that in both industries the use of opening clauses has stabilised at a level of about 10 percent of all firms. Opening clauses in Germany has been associated with higher wage increases (Fitzenberger and Franz 1999; Brändle and Heinbach 2010). On the basis of the 2011 IAB enterprise 
survey Ellguth et al. (2012:9) find that firms pay for these clauses with a 7 percent higher wage, but that the use of opening clauses triggers a reduction of 9 percent.

Specific one-off hardship clauses, related to the recession, in Germany's chemicals and metalworking sector agreements in 2009 and 2010 made it possible to vary the implementation of elements of the wage settlement in these years. In Finland, several sector agreements in 2010 included a similar clause allowing individual companies to adjust the agreed wage increase to reflect their own financial circumstances. In Norway, a one-off opening clause in most private sector agreements provided local negotiators with the option not to implement the sector increase agreed for 2009. Proposals of the industrial employers to add specific opening clauses to industry agreements have routinely been rejected by the Swedish unions. In 2009, however, under pressure of sharply rising unemployment combined with the government's refusal to raise the level of unemployment benefits, the metal workers union conceded a temporary two-years crisis agreement reminiscent of German-style opening clauses (Kjellberg 2012:63). In Austria, in addition, the 2011 metalworkers' collective agreement contains a clause allowing companies which in the last three years did not have a positive operating result to split the agreed wage increase for the sector in a general and a contingent part.

In Scandinavia there is no law that says that lower-level agreements must be more favourable. In Denmark, for instance, there is nothing that stands in the way of temporarily lowering a given standard. ${ }^{15}$ In the Netherlands, too, this is not a matter of law, and it is possible to gain exemptions even from an extended agreement with mandatory provisions. Yet, in neither country the unions conceded a specific opening clause related to the current recession, presumably because current sectoral agreements are already flexible enough. The same may be true for Switzerland. In both countries examples are from the past. In the Netherlands the 1982 central agreement spurred the adoption of a mandatory 'opening clause' of all agreements expiring after December 1982 allowing the suspension of price indexation in 1983 (Visser and Hemerijck 1997). In 1993 the agreement in machine tools in Switzerland introduced a temporary 'crisis clause' allowing firms falling on hard times to cancel the 'thirteenth month salary' and to increase working time without increasing wages (Bonoli and Mach 2000:158). The use of opening clauses in Belgium seems to be exceptional in the present recession (Keune 2011) and the law does not provide for exemptions, however in practice sectorally defined standards may be derogated from if the agreement explicitly allows for this through opt-out clauses. Three of the six main union confederations signed in 2013 a central agreement in France, subsequently enacted as law, introducing the possibility of derogation from sectoral standards for companies in economic difficulty subject to commitments to refrain from implementing redundancies.

In Southern Europe the hierarchical layering of agreements based on the favourability principle has usually found strict legal application (Sciarra 2006). However, under heavy international pressure, recent legal changes have opened Pandora's box. In Italy lowering sectorally agreed pay norms had been possible from 2001 in some 'underdeveloped' regions with high unemployment if there is a tripartite employment pact. The tripartite national pact of 2009, without approval of the largest union confederation, conceded the possibility to suspend the sectoral wage increase in firms that had fallen on hard times. In 2010 Fiat tested the pact by a round of concession bargaining including radical changes in working practices and dismissal protection in two of its plants, on threat 
of closure and relocation. Workers voted in favour in ballots organized by the company and the two plants were removed from the sector agreement. Soon after Fiat withdrew from the sector agreement. In June 2011 a new central agreement, with the signature of all three union confederations, stipulated that enterprise agreements can introduce temporary and experimental modifications of provisions in sector agreements within established limits and with approval by a majority of union delegates at the local level. These new rules have been applied in a few industry agreements since. When in August 2011 the government introduced, under pressure of the ECB, a decree-law with the possibility of derogation, by collective agreement, from legally-established dismissal protection guarantees, the main employers' confederation could only rescue the central agreement it had just signed by promising not to use the new law. This has prompted Fiat to leave the confederation.

In Spain there had been attempts to apply 'inability to pay' clauses in collective agreements even before the Recession. The 2010 legal reform widened the scope for the non-application of higher-level agreements on wages and other working conditions, especially working hours, at company level (Molina and Miguélez 2013: 23). The 2011 reform, still by the socialist government, aimed at giving priority to enterprise bargaining. In their framework agreement, of February 2012 the central union and employers' associations took this up and allowed a greater use of opening clauses on a wider range of issues-working time, remuneration systems, shift work and work organization. These opting-out clauses can only be applied in case of a persistent drop of revenues, but that should not have been a major constraint during the deep recession in which the Spanish economy found itself. In Greece, a 2010 law introduced scope for company agreements to derogate from the wage and working time provisions of sector agreements in cases of economic hardship. The 2011 reform radicalized this by making sector and cross-sector agreements redundant regarding wages.

Irish and British collective agreements do not establish legally binding norms and there are no legal rules on favourability or opening clauses. Under the rules of the social pacts, until 2009, Irish companies could claim inability to pay, though the unions frequently fiercely contested such claims, especially where unions had no access to company financial data. New Irish legislation for collective agreements regulating the minimum wage in some sectors like cleaning, catering or construction sets out a detailed process by which individual firms can seek temporary derogation on grounds of inability to pay. These exemptions can last from 3 to 24 months and, in order to avoid abuse, employers cannot quality for exemption twice.

In CEE, companies falling on hard times often pay less than stipulated in the collective agreement and, even, below the mandatory minimum wage. For this they do not need opening clauses, besides the fact that most bargaining takes place at enterprise level. Some laws on collective bargaining, for instance in the Czech Republic and Slovakia, exclude derogation and forbid agreeing terms that are less favourable than those stipulated in the law or in higher-order agreements. The result is that in times of economic stress fewer agreements are signed and fewer agreements contain a wage rise guarantee.

In Poland it is rare for a collective agreement in the private sector to provide for wage and terms of employment that are more favourable than the minimum stipulated in the law. Many agreements stipulate conditions even below legal standards, although the 
proportion of agreements with sub-minimal norms appears to have decreased from about one-half to one-fifth of all agreements between 2005 and 2009, according to the state's inspectorate. In 2002 the then socialist government felt it necessary to amend the law and allow for the suspension of (clauses in) the collective agreement in case of financial hardship. The idea seems to have been that this additional flexibility would make collective bargaining more attractive for employers. The incidence of such hardship clauses increased in following years, but bargaining activity (number and coverage of agreements) decreased. Firms facing financial difficulties did not go to the trouble of suspending or renegotiating particular provisions in the collective agreement but rescinded the agreement instead (Towalski 2005).

Slovenia has a tighter regime of collective bargaining and in response to the growing number of firms finding themselves in breach with the sectoral agreement by delaying or not paying the agreed wages, the 2009 cross-sectoral agreement did contain an opening clause allowing companies operating at a deficit to postpone the basic pay rise by six months, subject to agreement with the local (company) union representatives.

\section{Bargaining coordination}

Bargaining coordination has been widely used and preferred over centralisation as an indicator to assess and explain wage developments (Soskice 1990; Nickell 1997; OECD 1997, 2004). It is defined as the integration or synchronization of pay policies of distinct bargaining units (Soskice 1990; Traxler and Brandl 2012) or "the degree to which minor players deliberately follow along with what major players decide" (Kenworthy 2001:75). While full centralisation and full coordination amount to the same (Soskice 1990), fully decentralised bargaining, at the level of companies, might be highly coordinated, for instance if all negotiations are conducted by the same union, or employers take advice from one major association before signing agreements. These examples are extreme but not fanciful. Austria comes close to the situation of one union (federation) monopolizing all employee representation existing in the country; the General Employers' Association in the Netherlands, while not signing agreements, assists in the preparation and negotiations of most of the five to seven hundred company agreements concluded each year. Conversely, highly centralised bargaining at the level of peak-level confederations can be rather uncoordinated, when there is poor monitoring and implementation at lower levels.

In order to rank the extent of wage bargaining coordination from high (5) to low (1) I have followed Kenworthy's indicator of the "degree, rather than the type, of coordination" (2001:78), which links particular institutional features, as identified in Traxler et al. (2001), to more or less coordination. I have adjusted his scores and distinguish between coordination based on the issuing (by central agreement, government order, or a combination of these) of a binding ceiling or maximum/minimum rate of wage increases (=5); of wage norms, guidelines, patterns or recommendations issued by central organizations or established by a dominant sector, union or employers' association $(=4)$; of negotiation (and conflict mediation) procedures and guidelines issued by central organizations for lower-level bargainers $(=3)$; some form of government coordination through the setting of minimum wage or public sector examples $(=2)$; or none of the above (=1) (Table 4). 
Table 4 Wage Bargaining Coordination, 1995-2014

\begin{tabular}{|c|c|c|c|c|}
\hline & 1995-99 & 2000-04 & 2005-09 & 2010-14 \\
\hline Belgium & 4.6 & 5.0 & 5.0 & 5.0 \\
\hline Finland & 4.6 & 4.6 & 3.8 & 4.6 \\
\hline Sweden & 3.4 & 4.0 & 4.0 & 4.0 \\
\hline Norway & 4.0 & 4.2 & 4.0 & 4.0 \\
\hline Denmark & 3.8 & 4.0 & 4.0 & 4.0 \\
\hline Germany & 3.6 & 3.6 & 4.0 & 4.0 \\
\hline Austria & 4.0 & 4.0 & 4.0 & 4.0 \\
\hline Netherlands & 4.0 & 4.0 & 4.0 & 4.0 \\
\hline Japan & 4.6 & 4.0 & 4.0 & 4.0 \\
\hline Luxembourg & 2.0 & 2.0 & 2.4 & 3.2 \\
\hline Slovenia & 2.8 & 4.0 & 4.0 & 3.0 \\
\hline Spain & 2.0 & 3.2 & 3.6 & 3.0 \\
\hline Switzerland & 3.0 & 3.0 & 3.0 & 3.0 \\
\hline Korea & & 3.0 & 3.0 & 3.0 \\
\hline Italy & 3.0 & 3.0 & 2.9 & 2.5 \\
\hline Romania & 2.0 & 2.5 & 3.8 & 2.4 \\
\hline Slovakia & 2.2 & 1.8 & 2.0 & 2.4 \\
\hline France & 2.0 & 2.0 & 2.0 & 2.0 \\
\hline Portugal & 2.8 & 2.0 & 2.0 & 2.0 \\
\hline Czech Rep & 2.0 & 2.0 & 2.0 & 2.0 \\
\hline Australia & 2.0 & 2.0 & 2.0 & 2.0 \\
\hline Israel & & 2.0 & 2.0 & 2.0 \\
\hline Greece & 4.0 & 4.0 & 4.0 & 1.8 \\
\hline Bulgaria & 2.0 & 2.0 & 2.4 & 1.6 \\
\hline Hungary & 2.0 & 2.0 & 2.0 & 1.2 \\
\hline Ireland & 5.0 & 5.0 & 4.2 & 1.0 \\
\hline Estonia & 1.0 & 1.8 & 1.8 & 1.0 \\
\hline UK & 1.0 & 1.0 & 1.0 & 1.0 \\
\hline Latvia & 1.0 & 1.0 & 1.0 & 1.0 \\
\hline Lithuania & 1.0 & 1.0 & 1.0 & 1.0 \\
\hline Poland & 1.0 & 1.0 & 1.0 & 1.0 \\
\hline Canada & 1.0 & 1.0 & 1.0 & 1.0 \\
\hline USA & 1.0 & 1.0 & 1.0 & 1.0 \\
\hline Mexico & & 1.0 & 1.0 & 1.0 \\
\hline Chile & & 1.0 & 1.0 & 1.0 \\
\hline New Zealand & 1.0 & 1.0 & 1.0 & 1.0 \\
\hline Turkey & & 1.0 & 1.0 & 1.0 \\
\hline
\end{tabular}

Source: J. Visser, ICTWSS database, version 5.0

Based on this scale, there is a clear divergence between the mean level and development of coordination in Western Europe, the CEE and the non-European countries of the OECD (Fig. 4, left panel). Outside Europe any degree of coordination beyond state guidance through minimum wage setting or public sector wages is rare. This has not changed much during the recession: there was little wage coordination and this has remained to be the case. Japan and to a lesser extent Korea are the exceptions. Taking 


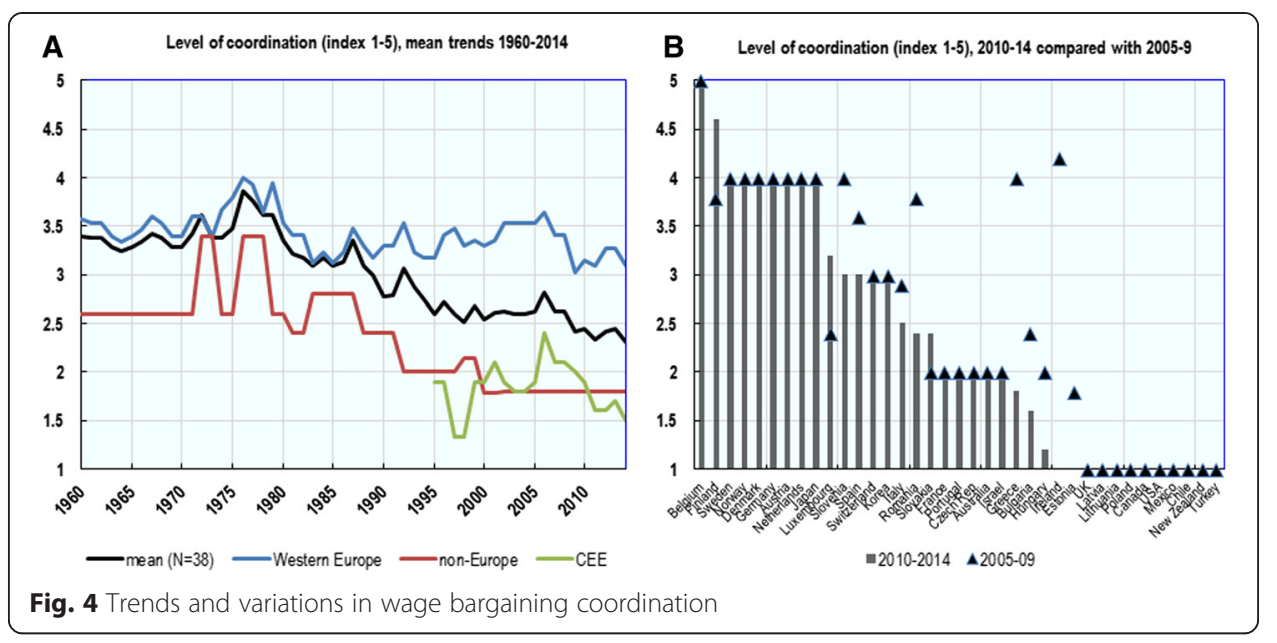

the annual wage increase set by the leading firms in major industries as benchmark, in both countries smaller companies, government agencies, and non-unionized employees negotiate their wages during one annual round (Sako 1997).

In CEE there were attempts at coordination before the recession in some countries. In Romania the termination of national, cross-sector agreements has weakened coordination across sectors, especially now wage bargaining has moved to the company level and most employees are no longer covered by collective bargaining arrangements. Slovenia had been the exception among the post-communist countries with a rather highly organized system of industrial relations (Bohle and Greskovits 2012) and it has been "the only post-communist society where social pacts have been concluded systematically since the mid-1990s and have also been influential ... (Stanojević and Krašovec 2011:232)". However, during the recession this ended and with fewer sectoral and no cross-sectoral agreement on wages, there is much less coordination than in the past. In Hungary, until 2011, employers and trade unions, although very divided and fragmented, issued a joint recommendation for wage increases within the framework of the now abolished tripartite consultation body. Since 2011 the government issues its own recommendations, but it is unclear whether these are followed. In Slovakia, countering the weakening of sectoral bargaining, the existing informal coordination across sectors was in 2013 augmented by the establishment of a formal bi-partite social dialogue arrangement for industry. Elsewhere in CEE, for instance in the Czech Republic where the government froze the statutory minimum wage for several years after 2008, the minimum wages is used as a tool to send messages to wage bargainers.

As can be seen from Fig. 4 (right panel) the level of coordination of wage bargaining has been rather stable in most countries in Western Europe with only some dramatic changes.

With the end of the national agreement in 2010, government's intervention was the only source of coordination in Greece. There is some evidence that before 2010 'protected' sectors (the public utilities and state monopolies such as electricity, telecommunications, airways, banking, railways, etc.) had a wage-leadership role, compared to the 'exposed' sectors mainly in manufacturing and commerce." (Ioannou 1998:103), but that surely ended and the current situation is one of enterprise bargaining with no horizontal coordination. Ireland has moved back to mostly uncoordinated company-level 
bargaining after the end of 22 years of tripartite wage agreements. The Irish trade union confederation and business association did not break off relationships altogether but signed a protocol with some ground rules for company-level negotiations but these do neither try to provide horizontal coordination on pay demands or settlements nor do they establish firm rules for settling conflicts over union recognition, a hotly disputed issue already before the break down of social partnership (Regan 2013).

Belgium continued with central wage settlements, since 2011 imposed by the government and within narrow margins set by legislation tying maximum wage increases to developments in neighbouring countries. Finland has returned to tripartite incomes policy pacts. "There are a limited number of things that Finland can affect on its own"- so Finland's prime minister (and current EU Commissioner) Jyrki Katainen when the deal for 2011-12 was announced - "A pay contract supporting industrial peace and competitiveness, purchasing power and employment is in our hands." In the Netherlands the main union confederations has since 1993 issued an annual recommendation on maximum wage increases, depending on past developments in inflation and productivity, and in any given year actual wage increases have stayed below this maximum (De Beer 2013). At times of economic downturn the government works hard and is usually capable to cast a "shadow of hierarchy" over bargaining tables in order to obtain a commitment to additional wage moderation (Visser and Van der Meer 2011). Moderation of wage demands in 2009-10 was tied to government and employer support for financing temporary shorter working hours, following the successful German example in metal engineering. In Italy the central organizations of unions and employers have set rules for sectoral and company bargaining through tripartite pacts (1993; 1998; 2009), but especially the 2009 pact was disputed by the largest union confederation and caused disunity within the employer camp, later followed by the exit of Fiat from the employers' confederation. In Spain, the annual cross-sectoral agreements between the central union and employers' organizations included from 2002 to 2008 rules as well as pay guidelines for sector and company negotiators based on inflation estimates. No agreement was reached in 2009, but in following years central coordination on bargaining rules was resumed without indexation-based pay recommendations.

Trendsetting arrangements have become dominant in Austria, Denmark, Norway, and Sweden, and always were in Germany. Outside Europe, the Australian award system created in its high days an "almost automatic transmission of wage gains from one sector to another" (Schwartz 2000:76) but this ended before the 1980s when coordination of union wage behaviour was based on an Accord with the government. After several modifications this ended in the 1990s and with the present mix of industry and company bargaining there is little coordination. In the USA pattern bargaining had been strongest in the auto-industry and "informally had served to centralize bargaining at the multi-employer level" (Katz 1993:11), but within and between industries pattern setting weakened and became ineffective in the 1980s.

A high level of employer organization and strong unions, especially in manufacturing, combined with pattern bargaining allowed Germany in the 1970s and 1980s to emulate the high degree of wage bargaining coordination found in Scandinavia during these years. With IG Metall as pacesetter, "other industries settled wage increases within 1 percent of the engineering agreement." (Jacobi et al. 1992:248)."This model has survived the turbulence of German reunification and declining rates of organization in 
manufacturing, both on the employers' and unions' side. Still, IG Metall is very powerful and acts as the pace-setter, for instance in the initial phase of the recession when it negotiated a 'shorter working hours' schedule and, in direct contact with the government, a car wrecking subsidy scheme.

Since the early 1980s, the metal-engineering industry has de facto gained the role of wage leader in Austria (Traxler 1998). Whether this will change after the decision of employers, in 2012, to leave the joint bargaining platform of the six branches making up the metalworking sector and sign separate agreements is as yet unclear. Thus far, it appears that the six agreements resemble each other. However, it sets a clear sign that employers want more differentiation.

Coordination based on trendsetting is of a more recent vintage in Scandinavia. The change from central level bargaining to coordinated industry bargaining, following the pattern set by the main agreements in the exposed sector, meant that wage leadership shifted from unskilled workers in the private and public sectors (the main benefactors of central agreements) to the skilled workers in the private (exposed) sector, with an increased role for salaried employees in later years (Bøje and Madsen 1994; Due et al. 1994; Iversen 1999). In each of these countries the changes started in the 1980s, but it took till the early (Denmark), mid (Norway) or late 1990s (Sweden) before a stable wage leadership was established (Scheuer 1998; Elvander 2002; Vartiainen 2001; Kjellberg 2012).

The effectiveness of trend-setting arrangements depends on whether the negotiators of the pattern setting agreement are able and willing to 'internalize' the pressures of international competitiveness and changing labour markets. This might be the case if the internationally exposed sector takes the lead. The stability of pattern setting, including wage moderation if need be, depends on a degree of centralisation and authority that is perhaps less than central wage bargaining but still formidable. This is nowhere clearer than in Austria where both the union and employers' side hold an absolute monopoly of representation, backed by the law, and can therefore not be challenged from without. In Germany it is the sheer might of the IG Metall in combination with the size, success and prestige of the car industry. In Norway and Denmark it is possible to end disputes over the renewal of agreements by means of a single mediation procedure for the entire private sector, empowering the mediator to treat several settlements as one entity in the ballot (Elvander 2003). This is a strong centralising element in an otherwise decentralised system of wage setting like the Danish one and a method to gag independent unions and out-of-step employers, for instance in the Norwegian oil industry. Mediation institutions were set up in all four Nordic countries in the early 20th century (Elvander 1990), but these institutions have been weaker in Sweden, where a strong doctrine of freedom from state interference in these matters had prevailed (Elvander 2002:210). This was addressed in the 1997 Industry Agreement between the industrial engineering employers and a cartel of ten unions. The agreement established a private-law mediation institute, a permanent joint structure with impartial chairpersons for negotiations and a sectoral Economic Council with four independent academic economists. Elvander and Holmlund (1997) judge these institutions as prerequisite for decentralized wage formation in a highly organized economy with powerful unions. In 2009 the employers in industrial engineering Employers Federation gave notice to the 1997 agreement, but it was renewed in 2011 with more power for 
impartial mediators, stricter negotiation rules and stronger incentives to maintain the manufacturing industry's wage leadership role. This came after a challenge during the recession, when some unions pushed hard for the norm to be set by the commercial services sector rather than by a manufacturing sector which was experiencing tremendous difficulties in exports and sales, and was rapidly losing jobs (Kjellberg 2012). In the 2011 bargaining rounds, following some recovery, the industry sector prevailed however, though with the salaried employees rather than the blue-collar unions, settling first and thus establish the pattern.

France is the most prominent case of state-guided coordination (Crouch 1993; Culpepper 2006). The Salaire Minimum Interprofessionelle Garantie (SMIC) was and still is a central instrument in shoring up France's entire wage structure. Setting its level became highly politicized, playing big in presidential elections. State guidance through setting the minimum wage or awards is primordial in France, Australia, the Czech Republic, Bulgaria, Turkey, Israel and, since 2010, in Greece and Portugal. During the recession government control over minimum wage setting has increased through the removal of the social partners from decision making over minimum wage levels (Greece, Hungary, Spain, Latvia), or by freezing (Ireland, Portugal, Latvia, Lithuania, Czech Republic), (partially) de-indexing (Belgium, Luxembourg) or lowering (Greece) the statutory minimum wage. Minimum wage setting by the government may have a big knock-on effect on private sector wage bargaining, especially where there is a large low wage sector and where wage bargaining institutions are weak or have weakened, as indicated by low and declining coverage rates, arrears in the renewal of agreements, and arrears in pay.

Summing up, the divide within Europe and between a part of Western Europe (plus Japan and Korea?) and the rest of the OECD universe has become sharper. High bargaining coverage and bargaining coordination tend to go together, and so do low coverage and coordination ( $r=.70$, for 37 countries, 2010-14). Thus, at higher levels of bargaining coverage (and unionization), governments, employers' associations and union federations appear to invest more in the co-ordination of wage bargaining. It is at very low levels of unionization and bargaining coverage that wage bargaining is allowed to go un-coordinated.

\section{Conclusions}

Collective bargaining and many of its underpinning laws and institutions are the product of major crises, not least the Great Depression of the 1930s, which became the inspiration for multi-employer bargaining and the rules that for half a century and longer ensured wide-ranging coverage of wage agreements. In the United States these were the founding years of industrial unions organizing across firms in mass production industries. In post-war Western Europe multi-employer bargaining at national and sectoral levels became the cornerstone not only of wage setting but also of labour market regulation more generally. After 1989 the labour laws in post-communist Europe made explicitly room for multi-employer bargaining. Although collective bargaining changed in many ways both in content and structure, the multi-employer nature of bargaining remained remarkably stable, at least in continental Western Europe and until the Great Recession. 
The recommendations of the Euro-Plus Pact of March 2011, the supervisory mechanism in the 'Six Pack' of regulations on economic governance adopted by the European Council in October 2011, and the Memoranda of Understanding between the troika of European and international institutions (the European Central Bank, the European Commission and the International Monetary Fund) and national governments in countries receiving financial assistance, goes invariably in the direction of reforms that weaken multi-employer bargaining and coordination across bargaining units. This is the exact opposite of the lessons and policies with which the industrialised democracies had tried to defeat the economic and political misery and upheavals of the 1930s and 1940s. Undoubtedly, labour markets changed in these eighty years - more technology, education, women, and probably also more rights and democracy in the workplace, as well as fiercer international competition on a global scale and intensely restless financial movements and interests - but one wonders how strong the evidence against multi-employer bargaining is that the destruction of its supporting institutions is currently taken for granted by so many governments.

In the 1980s the United Kingdom had been the first and only European country with a government determined to end the prevailing system of multi-employer bargaining. Its approach had been preceded in the USA and found followers in New Zealand and Australia, but none in Europe. In the 1990s as part of its 'Jobs Strategy', the OECD advised its members to "refocus collective bargaining at sectoral level to framework agreements, in order to give firms more leeway to adjust wages to local conditions; introduce opening clauses for local bargaining parties to renegotiate sector agreements; (and) phase out administrative extension" (OECD 1994). These are the policies advocated, with more coercion, by the international institutions (IMF, EU, ECB) as part of their financial assistance programs during the current recession and souvereign debt crisis. Ten or fifteen years ago the OECD's advise had no takers (OECD 1999) and in a follow up analysis in 2004 the organization admitted that the evidence had probably not been as straightforward and convincing as had been presented in the 1994 study (OECD 2004). In addition to "persistent doubts concerning the efficacy of the policy recommendations" (OECD 2004:132), the organization conceded that the general trends of rising wage inequality and persistence of low pay had made governments wary of instituting reforms that tend to make such trends worse (ibid.). The OECD also noted that the power of governments in this policy domain is often limited, not only because of union opposition, but also because wage-setting institutions "are deeply embedded in the social and economic fabric" of member states (ibid.). Apparently, it needs a severe crisis and much international pressure to disembed wage bargaining institutions. In its final evaluation of the Jobs Strategy, the OECD concluded that under conditions of efficient coordination inclusive bargaining models (based on wide-ranging coverage, achieved with some form of centralised or coordinated bargaining, the help of administrative extension, and/or high rates of unionisation) can perform as good as the exclusive, decentralised systems it had initially recommended (OECD 2006).

As we have seen in the pages before, the Great Recession and its Aftermath intensified rather than changed developments in wage bargaining institutions, like decreasing bargaining coverage, lower unionization levels, and decentralisation of wage bargaining. The regulatory changes, concentrated in Southern and Eastern Europe, contributed to what appears to be a convergent global trend to "restoring market control by making 
the basis for organised interests smaller and more exclusive" (Goldthorpe 1984: 330), a trend in which European wage bargaining institutions become more similar to what is the norm outside Europe. This shrinkage of collective representation and bargaining is the expression of, and a contribution to, the observed rise in inequalities in the labour market and in society (Jaumotte and Buitron 2015).

In one aspect - state intervention and the conspicuous absence of social pacts - the Great Recession appears to present a political break with developments since the 1990s, however. The European Commisson's most recent report on Industrial Relations in Europe (EC 2015) notes that as regards state intervention in wage setting, there is no overall common trend across EU Member States. Whereas before the crisis there were signs of less direct state intervention both inside and outside Europe, during the Recession governments in Europe have become more involved in wage-setting. Again, this is especially true for EU Member States receiving external financial support, such as Romania, Greece, Portugal and Spain, where government interventions have reduced the scope for collective bargaining and pushed disorganised decentralisation. In Italy, under pressure of the European Central Bank, the government tried to force change upon employers and unions, and in Belgium and Luxembourg, over the issue of indexation, governments were under pressure of the European Commission, though in Belgium and Italy the unions were less easily pushed aside. But generally in these and other countries where the rules on minimum wage setting, extension, treatment of expired agreements, enterprise agreements, hierarchy of bargaining levels, union recognition and opening clauses have been changed, "government imposition was a more prevalent institutional source of change than negotiation between employers and trade unions for a larger number of changes" (Marginson and Welz 2014).

This stands in contrast to the trend towards more social dialogue and search for concerted policies in the years prior to the Great Recession, both inside and outside Europe (Fraile and Baccaro 2010; Avdagić et al. 2011). Social pacts, defined as policy contracts between governments, trade unions and employers' associations over wage, labour market and welfare policies, had been rediscovered in the 1990s as instruments to gain the support of unions for wage moderation and reforms in wage setting, for instance in preparation of a common monetary policy and currency (Pochet and Fajertag 2000). Considering cases as different as Slovenia, Poland, South Korea and Chile, Fraile and Baccaro (2010) find support for the hypothesis that these pacts, while not changing the (neo-liberal) direction of change moderated its pace, provided compensation for those groups and interests that were losing due to changes and thus made reform more politically sustainable. During the Great Recession wage setting reform pacts are conspicuous by their absence and international pressure appears to have substituted for the search for domestic consensus.

This conclusion is supported by the finding that in the countries hit hardest during the recession and with the largest number of regulatory changes, wage bargaining coordination has more or less disappeared (Fig. 4). The Great Recession has sharpened the divide between a smaller group of countries with more cohesive and coordinated industrial relations and wage bargaining institutions, and lower inequality levels, and a larger group of countries where 'markets make policies', wage bargaining institutions are divisive and uncoordinated, and income inequality levels are higher. 


\section{Endnotes}

${ }^{1}$ I want to thank Tony Atkinson, Georg Fisher, Juan Jimeno, Olivier Blanchard, Prakash Loungani, and the anonymous reviewer of this journal, for their inspiring comments, questions and suggestions. Further thanks go to Ecfin officials Alphonso Arpaia, Karl Pichelmann and Allessandro Turini for critique and support. The author is also grateful to collegues within the European Industrial Relations Observatory in the European Foundation for the Improvement of Living and Working Conditions in Dublin for their help with particular questions, and to Sebastien Martin at the OECD and Susan Hayter and Rosina Gammarano at the ILO for help with statistics on employment, union density and bargaining coverage. Needless to say, that the interpretation of the data, the conclusions, judgments and errors are the author's sole responsibility.

${ }^{2}$ J. Visser, ICTWSS Database, version 5.0, released August 2015, Amsterdam: Amsterdam institute for Advanced Labour Studies (AIAS); http://www.aias-uvanet.nl. The construction of the variables in this paper (adjusted coverage, extension regimes, dominant level of bargaining, articulation, additional enterprise bargaining, opening clauses, decentralisation, and coordination) is explained in the ICTWSS codebook and available with the dataset.

${ }^{3}$ All current (34) member states of the Organisation for Economic Cooperation and Development (OECD) plus EU Members Bulgaria, Latvia, Lithuania and Romania.

${ }^{4}$ The observed coverage rate includes employees directly covered through their membership of a union or employment in a firm directly bound by collective agreement as well as employees who are bound due to the extension of the agreement to non-organized firms. The separate effect of extension orders are discussed below.

${ }^{5}$ Union density and bargaining coverage rate are calculated in the same way, as the proportion of employees who have taken up membership of a union and employees whose terms of employment are covered by a collective agreement. Besides a few countries were the data are derived from household or labour market surveys, the data are from administrative records. Union density rates are calculated net of retired, unemployed and self-employed members; bargaining coverage rates are calculated on the basis of 'existing' agreements, including those that have been concluded in earlier years. This tends to produce an inflated bargaining coverage rate when agreements have no expiration date, have not been renewed on a regular basis and are treated as valid even when expired. For and explication and example, see the note on Portugal (Additional file 1).

${ }^{6}$ From 1960 to 1989 the average length of union recognition elections increased from 54 days to 212 days, with ever fewer cases won by the unions (Peters 2005). The hostilities produced during these elections was such that it became less and less like that there will be a collective agreement.

${ }^{7}$ Calculated from "Quadros de Pessoal" 1999-2014; Ministério da Solidariedade e Segurança Social. http://www.gep.msess.gov.pt/estatistica/gerais, and Directorate of labour relations, DGERT, Variação média ponderada intertabelas and DGERT, Instrumentos de regulamentação colectiva de trabalho publicados; GEE, Boletim Estatístico, January 2014 and January 2015.

${ }^{8}$ Quadros de Pessaol, Ministério da Solidariedade e Segurança Social. http:// www.gep.msess.gov.pt/estatistica/gerais.

${ }^{9}$ Ministerio de Empleo y Seguridad Social. Observatorio Negociación Colectiva, Boletín 45, Augosto-Septiembre 2014, actualizacion 
${ }^{10}$ ISTAT (Italian National Statistical Office) "Contratti collettivi e retribuzioni contrattuali 2014", Rome, January 2015; www.istat.it/it/archivio/contratticollettivi

${ }^{11}$ Ministère du Travail, de l'Emploi et du Dialogue Social 2014 La négociation collective en 2013, Bilans \& Rapports. http://travail-emploi.gouv.fr/IMG/pdf/

${ }^{12}$ Ministère du Travail, de l'Emploi et de la Santé 2012 La négociation collective en 2011, Bilans \& Perspectives, Paris, 320. http://travail-emploi.gouv.fr/IMG/pdf/

${ }^{13}$ The actual level of wage bargaining has been calculated by applying the following formula: L - ((fAEB + GOC)/max value $)+(($ Art + DR-1)/max value $)$, where $\mathrm{L}=$ dominant level of bargaining; $f \mathrm{AEB}=$ frequency of additional enterprise bargaining; $\mathrm{GOC}=$ existence of general opening clauses in sectoral agreements; $\mathrm{ART}=$ articulation of multi-level bargaining; and $\mathrm{DR}=$ legal or contractual basis for derogation from sectoral or legal norms.

${ }^{14}$ These 'associations of persons' had been introduced in Greek labour law in 1982 for the purpose of ensuring worker representation for specific tasks. They were not considered as 'union bodies', as their existence was limited to a maximum duration of six months, could not sign collective agreements and did not have the legal rights and protection of union delegates (Mark Carley, Works Councils: Workplace Representation and Participation Structures. Dublin: European Foundation for the Improvement of Living and Working Conditions, report 2005)

${ }^{15}$ 'The mentioned understanding of opening-clauses (as a general rather than hardship clause, auth) is the basic rule of centralized decentralization in Denmark' (Jørgensen 2005). Usually, derogation do not go below the sectoral minimum on pay. 'In the trendsetting collective agreement in Industry, however, a recently inserted experimental paragraph (spring 2004) gives the parties to the agreement the opportunity to overrule a number of central issues in the collective agreement and stipulate their own rules concerning the issue' (ibid.)

\section{Additional file}

Additional file 1: Assessing union density and bargaining coverage in Portugal. (DOCX $128 \mathrm{~kb}$ )

\section{Competing interest}

The IZA Journal of Labor Policy is committed to the IZA Guiding Principles of Research Integrity. The author declares that he has observed these principles.

\section{Acknowledgement}

The author would like to thank the anonymous referee.

Responsible editor: Juan F Jimeno

Received: 25 March 2015 Accepted: 4 January 2016

Published online: 13 May 2016

\section{References}

Addison JT (1981) Incomes policy: the recent european experience. In: Fallick JL, Elliott RF (eds) Incomes Policies, Inflation, and Relative Pay. Allen \& Unwin, London, pp 187-245

Addison JT, Teixeira P, Evers K, Bellmann L (2014) Indicative and updated estimates of the collective bargaining premium in Germany. Ind Relat 53(1):125-156

Addison JT, Portugal P, Vilares H (2015a) Unions and Collective Bargaining in the Wake of the Great Recession. IZA Discussion Paper No.8943, Institute for the Study of Labor, Bonn, Germany

Addison JT, Teixeira P, Evers K, Bellmann L (2015b) Pacts for Employment and Competitiveness as a Role Model? Their Effects on Firm Performance. IZA Discussion Paper No. 9323, Institute for the Study of Labor, Bonn, Germany

Aidt TS, Tzannatos Z (2008) Trade unions, collective bargaining and macroeconomic performance. Ind Relat J $39: 258-295$ 
Armingeon K (1982) Neokorporatistiche Einkommenspolitiik. Eine vergleichende Untersuchung von Einkommenspolitiken in westeuropäischen Ländern in den 70er Jahren. Haag und Herchen, Frankfurt a.M

Avdagić S, Rhodes M, Visser J (2011) Social Pacts in Europe: Emergence, Evolution and Institutionalization. Oxford University Press, Oxford

Barreto J (1992) Portugal: Industrial relations under democracy. In: Ferner A, Hyman R (eds) Industrial Relations in the New Europe. Blackwell, Oxford, pp 298-322

Beneyto PJ (2008) El sindicalismo español en perspectiva europea: de la anomalía a la convergencia. Cuadernos de Relaciones Laborales 26:57-88

Blanchflower D, Bryson A (2003) Changes over time in relative union wage effects in the UK and the USA revisited. In: Addison JT, Schnabel C (eds) International Handbook of Trade Unions. Edward Elgar, Cheltenham

Bohle D, Greskovits B (2012) Capitalist Diversity on Europe's Periphery. Cornell University Press, Ithaca NY

Bøje TP, Madsen PK (1994) Wage Formation and Incomes Policy in Denmark in the 1980s. In: Dore R, Boyer R, Mars Z (eds) The Return to Incomes Policy. Pinter, London, pp 94-117

Bonoli G, Mach A (2000) Switzerland: Adjustment politics within institutional constraints. In: Scharpf FW, Smidt VA (eds) Work and Welfare in the Open Economy. Oxford University Press, Oxford, pp 131-174

Brändle T, Heinbach WD (2010) Opening Clauses in Collective Bargaining Agreements. More flexibility to save jobs? In: IAW DP 67. University of Tübingen, Economics Dept, Tübingen

Calmfors L (1990) Wage Formation and Macroeconomic Policy in the Nordic Countries: A summary. In: Calmfors L (ed) Wage Formation and Macroeconomic Policy in the Nordic Countries. SNS/Oxford University Press, Stockholm and Oxford, pp 11-60

Costa HA (2012) From Europe as a model to Europe as austerity: the impact of the crisis on Portuguese trade unions. Trans Eur J Labour Res 18:397-410

Crouch CJ (1993) Industrial Relations and European State Traditions. Oxford University Press, Oxford

Culpepper P (2006) Capitalism, Coordination and Economic Change. The French Political Economy Since 1985. In: Culpepper P, Hall P, Pallier B (eds) Changing France. The Politics that Markets Make. Palgrave-McMillan, London

de Beer PT (2013) De Nederlandse arbeidsverhoudingen 30 jaar na Wassenaar. In: de Beer PT (ed) Arbeidsverhoudingen onder druk, Preadviezen Koninklijke Vereniging van Staathuishoudkunde. SDU, The Hague

Dedoussopoulos A, Aranitou V, Koutentakis F, Maropoulou M (2013) Assessing the impact of the memoranda on Greek labour market and labour relations. ILO, Geneva, report no. 483774

Due J, Madsen JS, Jensen CS, Petersen LK (1994) The Survival of the Danish Model. A historical sociological analysis of the Danish system of collective bargaining. DJØF Publishing, Copenhagen

EC (2004) Industrial Relations in Europe 2004. Office for the Official Publications of the European Commission, Luxembourg

EC (2015) Industrial Relations in Europe 2014. Office for the Official Publications of the European Commission, Luxembourg

Ellguth P, Kohaut S (2008) Ein bund fürs überleben? betriebliche vereinbarungen zur beschäftigungs- und standortsicherung. Indust Bezieh 15:209-232

Ellguth P, Gerner H, Stegmaier J (2012) Wage Bargaining in Germany. The role of works councils and opening clauses. IAB Discussion Paper 5/2012

Elvander N (1990) Incomes policies in the Nordic countries. Int Labour Rev 29:1-21

Elvander N (2002) The New Swedish Regime for collective bargaining and conflict resolution: a comparative perspective. Eur J Ind Rel 8:197-216

Elvander N (2003) Two labour market regimes in Sweden. A comparison between the Saltsjöbaden Agreement of 1938 and the industry agreement of 1997. Indust Bezieh 10:146-159

Elvander N, Holmlund B (1997) The Swedish bargaining system in the melting Pot: institutions, norms and outcomes in the 1990s. Arbetslivsinstitutet, Solna

Erne R (2011) European unions after the crisis. In: Burroni L, Keune M, Meardi G (eds) Economy and society in Europe: a relationship in crisis. Edward Elgar, Cheltenham

Felbermayr G, Baumgarter D, Lehwald S (2014) Wachsende Lohhungleichkeit in Deutschland. Bertelsmann Stiftung, Gütersloh

Fitzenberger B, Franz W (1999) Der Flächentarifvertrag. Eine kritische Würdigung aus oekonomischer Sicht". In: Franz W Ramser H-J, Stadler M (eds) Ökonomische Analyse von Verträgen. Mohr Siebeck, Tübingen

Flanagan RJ (1993) The United States: Decentralized Heterogeneity. In: Hartog J, Theeuwes J (eds) Labour Market Contracts and Institutions. A cross-national comparison. North-Holland, Amsterdam, pp 31-76

Flanagan RJ (1999) Macroeconomic performance and collective bargaining: an international perspective. J Econ Lit $37: 1150-1175$

Flanagan RJ, Soskice DW, Ulman L (1983) Unions, Economic Stabilisation and Incomes Policies: European experience. The Brookings Institution, Washington, DC

Flanagan RJ, Hartog J, Theeuwes J (1993) Institutions and the Labour Market: Many questions, some answers. In: Hartog J, Theeuwes J (eds) Labour Market Contracts and Institutions. A cross-national comparison, North-Holland, Amsterdam, pp 415-46.

Flanders A (1968) Collective bargaining: a theoretical analysis. Br J Ind Relat 6:1-26

Fraile L, Baccaro L (eds) (2010) Blunting neoliberalism : tripartism and economic reforms in the developing world. ILO, Geneva García Blasco J, de Val Tena ÁL (2004) Collective Bargaining in Spain. In: Collective Bargaining in Europe. Ministerio de Trabajo y Asuntos Sociales, Comisión Consultiva Nacional de Convenios Colectivos, Madrid

Goldthorpe JH (1984) The End of Convergence: Corporatist and dualist tendencies in modern western societies. In: Goldthorpe JH (ed) Order and Conflict in Contemporary Capitalism. Studies in the Political Economy of Western European Nations. Clarendon, Oxford

Gonser M (2011) More of the same, but faster? The financial crisis and the representation of employee interests in the Baltic states. Trans Eur J Labour Res 17(3):409-414 
Guigni G (1965) Recent developments in collective bargaining in Italy. Int Labour Rev 91(4):273-291

Haipeter T (2013) Erosion, Exhaustion or Renewal? New Forms of Collective Bargaining In Germany. In: Arthurs H, Stone $\mathrm{K}$ (eds) Beyond the Employment Contract. Rusell Sage, New York

Hartog J, Leuven E, Teulings CN (2002) Wages and the bargaining regime in a corporatist setting: the Netherlands. Eur J Polit Econ 18:317-331

Heinbach WD (2005) Ausmasz und Grad der tarifvertraglichen Öffnung. University of Tübingen, Tübingen

Howell C, Kolins Givan R (2011) Rethinking Institutions and Institutional Change in European Industrial Relations. Br J Ind Relat 49:231-55

ILO (2014) Greece: Productive Jobs for Greece. International Labour Office, Geneva

IMF (2014) Fiscal Policy and Income Inequality. IMF Policy Paper, Washington DC

Ioannou CA (1998) EMU and Hellenic Industrial Relations. In: Kauppinen T (ed) The Impact of EMU on Industrial relations in European Union. Finnish Industrial Relations Association, Helsinki, publ. no. 9

loannou H, Papadimitriou K (2012) Collective bargaining in Greece in the years 2011 and 2012 - trends, breakthroughs and prospects". OMED report, Athens, April 2013

Iversen T (1999) Contested Economic Institutions. The Politics of Macroeconomics and Wage Bargaining in Advanced Democracies. Cambridge University Press, Cambridge, Mass

Jacobi O, Keller B, Müller-Jentsch W (1992) Germany: Co-determining the Future. In: Ferner A, Hyman R (eds) Industrial Relations in the New Europe. Blackwell, Oxford, pp 298-322

Jaumotte F, Buitron CO (2015) Inequality and Labour Market Institutions. IMF Staff Discussion Note 15/14, Washington DC

Jobert A, Saglio J (2005) La mise en oeuvre des dispositions de la loi du 4 Mai 2004 permettant aux entreprises de déroger aux accords de branche. Ministère de l'Emploi, du Travail et de la Cohésion Sociale, Paris

Jørgensen C (2005) Denmark. In: Schulten T (ed) Changes in National Collective Bargaining Systems Since 1990. European Foundation, Dublin, EIRO web report TN0503102S

Kädtler J (2003) Tarifpolitik und Tarifpolitisches System in der Bundesrepublik. In: Schroeder W, Weßels B (eds) Die Gewerkschaften in Politik und Gesellschaft der Bundesrepublik Deutschlands. Westdeutscher Verlag, Wiesbaden

Katz HC (1993) The decentralization of collective bargaining: a literature review and comparative analysis. Ind Labor Relat Rev 47:1-22

Kenworthy L (2001) Wage-setting institutions: a survey and assessment. World Politics 54:57-98

Keune M (2011) Decentralizing wage setting in times of crisis? The regulation and use of wage-related derogation clauses in seven European countries. Eur Labour Law J 2:86-94

Kézdi G, Kónya I (2011) Wage Setting in Hungary. Evidence from a firm survey. ECB: working paper series, no. 1378, Franfurt a.M

Kjellberg A (2012) Trade Unions and Collective Agreements in a Changing World. In: Thörnquist A, Engstrand A-K (eds) Precarious Employment in Perspective. Old and New Challenges in Working Conditions in Sweden. P.I.E. - Peter Lange, Brussels

Kochan TA, Verma A (1992) A Comparative View of of United States and Canadian Industrial Relations. A Strategic Choice Perspective. In: Gladstone A (ed) Labour Relations in a Changing Environment. Walter de Gruyter, Berlin/New York

Kohl H, Platzer H-W (eds) (2004) Industrial Relations in Central and Eastern Europe. Transformation and Integration. A comparison of eight new EU member states. ETUI, Brussels

Koukiadis DI (2009) General characteristics of Greek labour Law. Comp Labor Law Policy J 30:145-158

Kristal T, Cohen Y (2007) Decentralization of collective agreements and rising wage inequality in Israel. Ind Relat 46(3):613-635

Lallemand M (2006) New Patterns of Industrial Relations and Political Action since the 1980s. In: Culpepper P, Hall PA, Palier B (eds) Changing France, The politics that markets make. Palgrave, London, pp 50-104

Mach A, Oesch D (2003) Collective bargaining between decentralization and stability: a sectoral model explaining the Swiss experience during the 1990s. Indust Bezieh 10:160-182

Marginson P, Welz C (2014) Changes to wage-setting mechanisms in the context of the crisis and the EU's new economic governance regime. European Foundation, report, Dublin, http://www.eurofound.europa.eu/eiro/ studies/tn1402049s

Molina O, Miguélez F (2013) From negotiation to imposition: social dialogue in austerity times in Spain. ILO, Geneva, report no. 483344

Moore S, McKey S, Veale S (2014) Statutory Regulation and Employment Relations. The Impact of Statutory Trade Union Recognition. Palgrave-McMillan, London

Mundlak G (2007) Fading Corporatism. Israel's Labor Law and Industrial Relations in Transition. Cornell University Press, Ithaca NY

Nickell SJ (1997) Unemployment and the labour market rigidities: Europe versus North America. J Econ Perspect 11:55-74

OECD (1994) The OECD Jobs Study, Part II: The Adjustment Potential of the Labour Market. Organisation for Economic Co-operation and Development, Paris

OECD (1997) Economic performance and the structure of collective bargaining. Employment Outlook 1997:63-93

OECD (1999) Implementing the OECD Jobs Strategy: Assessing Performance and Policy, Organisation for Economic Co-operation and Development, Paris

OECD (2004) Wage-Setting Institutions and Outcomes. Employment Outlook 2004: chapter 3

OECD (2006) OECD Jobs Strategy: Lessons from a Decade's Experience. Main report, Organisation for Economic Co-operation and Development, Paris

OECD (2014) Does Income Inequality Hurt Economic Growth? OECD Focus on Inequality and Growth, Organisation for Economic Co-operation and Development, Paris

Palier B, Thelen K (2010) Institutionalizing dualism: complementarities and change in France and Germany. Politics Society 38(1):119-148

Pérez-Díaz V, Rodrigues JC (1995) Inertial Choices: An overview of Spanish human resources, practices and policies. In: Locke TKL, Piore M (eds) Employment Relations in a Changing World Economy. The MIT Press, Cambridge, MA, pp 165-196 
Peters N (2005) The United Kingdom recalibrates the U.S. National Labor Relations Act. Possible Lessons for the United States. ACAS, London, research paper 05/01

Pochet P, Fajertag G (eds) (2000) Social Pacts in Europe - New Dynamics. European Trade Union Institute/Observatoire Social Européen, Brussels, pp 9-40

Ramalho RP (2013) Portuguese Labour Law and Industrial Relations During the Crisis. ILO, Geneva, Report no. 483775

Regan A (2012) The political economy of social pacts in the EMU: Irish Liberal Market Corporatism in Crisis. New Pol Econ 17:465-491

Regan A (2013) The Impact of the Eurozone Crisis on Irish Social Partnership. ILO, Geneva, Working Paper 49

Saglio J (1995) Industrial Relations and Human Resources in France. In: Locke TKL, Piore M (eds) Employment Relations in a Changing World Economy. The MIT Press, Cambridge, MA, pp 267-2

Sako M (1997) Shunto: the role of employer and union coordination at the industry and inter-sectoral levels. In: Sako M, Sako H (eds) Japanese Labour and Management in Transition: Diversity, flexibility and participation. Routledge, London

Scheuer S (1998) Denmark: A Less Regulated Model. In: Ferner A, Hyman R (eds) Changing Industrial Relations in Europe. Blackwell, Oxford, pp 146-170

Schnabel C (1995) Entwicklungstendenzen der Arbeitsbeziehungen in der Bundersrepublik Deutschland seit begin der achziger Jahre. Eine Analyse unter besonderer Berücksichtigung der Arbeitgeberseite. In: Mesch M (ed) Sozialpartnerschaft und Arbeitsbeziehungen in Europa. Manzsche Verlags- und Universitätsbuchhandlung, Vienna

Schwartz H (2000) Internationalization and Two Liberal Welfare States: Australia and New Zealand. In: Scharpf FW Smidt VA (eds) Work and Welfare in the Open Economy. Oxford University Press, Oxford

Sciarra S (2006) The evolving relationship between collective bargaining and law in the Member States. In: E Commission (ed) Industrial Relations in Europe 2006. Official Publications of the European Commission, Luxembourg

Sisson K (1987) The Management of Collective Bargaining. Blackwell, Oxford

Soskice DW (1990) Wage determination: the changing role of institutions in advanced industrialised countries. Oxf Rev Econ Policy 6:36-61

Stanojević M, Krašovec A (2011) Slovenia: Social Pacts and Political Exchange. In: Avdagic S, Rhodes M, Visser J (eds) Social Pacts in Europe. Emergence, Evolution and Institutionalization. Oxford University Press, Oxford

Streeck W (2009) Re-Forming Capitalism: Institutional change in the German political economy. Oxford University Press, Oxford and New York

Towalski R (2005) Poland. In: Th S (ed) Changes in National Collective Bargaining Systems Since 1990. European Foundation, Dublin, EIRO webreport TN0503102S, Dublin

Traxler F (1995) Farewell to Labour Market Associations? Organized versus disorganized decentralisation as a map for industrial relations. In: Traxler F, Crouch CJ (eds) Organized Industrial Relations in Europe. What future? Aldershot Avebury, pp 3-19.

Traxler F (1998) Austria: Still the Country of Corporatism? In: Ferner ARH (ed) Changing Industrial Relations in Europe. Blackwell, Oxford, pp 239-261

Traxler F, Brandl B (2012) Collective bargaining, inter-sectoral heterogeneity and competitiveness: a cross-national comparison of macroeconomic performance. Br J Ind Relat 50:73-98

Traxler F, Blaschke S, Kittel B (2001) National Labor Relations in Internationalized Markets: A comparative study of institutions, change, and performance. Oxford University Press, Oxford

Vartiainen J (2001) Understanding Swedisch Social Democracy: victims of success? In: Glynn A (ed) Social Democracy in Liberal Times. The Left and economic policy since 1980. OUP, Oxford, pp 21-52

Visser J (2013) Flexibility and Security in Post-Standard Employment Relations: The Case of the Netherlands. In: Arthurs $\mathrm{H}$, Stone K (eds) Beyond the Employment Contract. Russell Sage, New York

Visser J (2015) The Institutional Characteristics of Trade Unions, Wage Setting, State Intervention and Social Pacts. ICTWSS Database, version 5.0. Amsterdam institute for Advanced Labour Studies, Amsterdam, http://www.aias-uvanet.nl

Visser J, Hemerijck AC (1997) A Dutch Miracle. In: Job Growth, Welfare Reform and Corporatism in the Netherlands. Amsterdam University Press, Amsterdam

Visser J, van der Meer M (2011) The Netherlands: Social Pacts in a Concertation Economy. In: Avdagic S, Rhodes M Visser J (eds) Social Pacts in Europe. Emergence, Evolution and Institutionalization. Oxford University Press, Oxford

Visser J, Hayter S, Gammarano R (2015) The coverage of collective bargaining: Stability, erosion or decline. ILO: Labour Relations and Collective Bargaining Policy Brief No.1

Xavier B (2004) Collective Bargaining in Portugal. In: Collective Bargaining in Europe. Ministerio de Trabajo y Asuntos Sociales, Comisión Consultiva Nacional de Convenios Colectivos, Madrid

Yannakourou M, Soumeli E (2004) The Evolving Structure of Collective Bargaining (1990-2004), National Report Greece and Cyprus, Unpublished report, written for comparative study of collective bargaining in Europe, directed by prof. S. Sciarra, Unitversity of Florence Project Co-financed by the European Commission and the University of Florence.

Zambarloukou S (2006) Collective bargaining and social pacts: Greece in comparative perspective. Eur J Ind Rel 12:211-229 